\title{
Analysis of Energy Use and Energy Savings: A Case Study of a Condiment Industry in India
}

\author{
Khan Rahmat Ullah ${ }^{1, *}$, Marudhappan Thirugnanasambandam ${ }^{2} \mathbb{D}$, Rahman Saidur ${ }^{3,4}$, Kazi Akikur Rahman 5 \\ and Md. Riaz Kayser ${ }^{6}$
}

1 School of Built Environment, Faculty of Arts, Design \& Architecture, UNSW Sydney, Sydney, NSW 2052, Australia

2 Department of Mechanical Engineering, Bannari Amman Institute of Technology, Tamil Nadu 638401, India; mtsambandam@gmail.com

3 Research Center for Nano-Materials and Energy Technology (RCNMET), School of Engineering and Technology, Sunway University, Bandar Sunway, Petaling Jaya 47500, Selangor Darul Ehsan, Malaysia; saidur@sunway.edu.my

4 Department of Mechanical and Manufacturing Engineering, Faculty of Engineering, University Putra Malaysia, Seri Kembangan, Serdang 43400, Selangor Darul Ehsan, Malaysia 5 Idaho National Laboratory, 1955 N Fremont Ave, Idaho Falls, ID 83415, USA; kaziakik@gmail.com

6 Solar Energy Technologies, Western Sydney University, Penrith, NSW 2751, Australia; mdriaz.kayser@inl.gov

* Correspondence: khan2020.unsw@gmail.com or k.ullah@unsw.edu.au; Tel.: +61-(41)-6308347

check for

updates

Citation: Ullah, K.R.;

Thirugnanasambandam, M.; Saidur,

R.; Rahman, K.A.; Kayser, M.R.

Analysis of Energy Use and Energy

Savings: A Case Study of a Condiment Industry in India. Energies 2021, 14 ,

4798. https://doi.org/10.3390/

en14164798

Academic Editors: Marco Marengo, Mahyar Silakhori and Antonio Rosato

Received: 17 June 2021

Accepted: 4 August 2021

Published: 6 August 2021

Publisher's Note: MDPI stays neutral with regard to jurisdictional claims in published maps and institutional affiliations.

Copyright: (c) 2021 by the authors. Licensee MDPI, Basel, Switzerland. This article is an open access article distributed under the terms and conditions of the Creative Commons Attribution (CC BY) license (https:/ / creativecommons.org/licenses/by/ $4.0 /)$.

\begin{abstract}
Electric motors and boilers lead the industrial components which consume the largest portion of energy in an industry. This study explores the energy audit data of the condiment industry in India. The study mainly focuses on the estimation of the load factor, energy use, energy savings and annual bill savings with payback period of the electric motors of the plant. During the audit, it was found that there were several motors running under loaded conditions despite non-availability of variable speed drives installed in the plant. Therefore, variable speed drives are recommended to be installed to save energy by reducing the motors speed by up to $60 \%$. According to the estimation, about $276 \mathrm{MWh}, 551 \mathrm{MWh}$ and 827 MWh electrical energy can be saved for $20 \%, 40 \%$ and $60 \%$ speed reduction of the motors using variable speed drives, respectively, where in most of the cases the payback period remains below 1 year. Furthermore, some suggestions are made to improve the poor power factor of running motors by using capacitor banks to save the reactive power. Besides, an estimation of energy saving is performed with a 2-ton capacity boiler. Since, there was no heat recovery system in the boiler; an air-preheater is suggested to be installed at the end of flue gas exhausting path of the boiler with the purpose of saving 68 tons of fuel per annum and having a payback period of 12 months. Moreover, a digital monitoring system, namely, "The Smart Joules" has been proposed to be installed in the plant aiming at saving about $3-5 \%$ of total energy per annum and having a payback period of 19 months. Finally, a summarization is made concluding in the fact that about 90 MWh energy and 95 tons of fuel can be saved (excluding motor energy savings) per annum by implementing proposed measures with a payback period of 15 months.
\end{abstract}

Keywords: condiment industry; energy audit; energy savings; motors; boilers

\section{Introduction}

The efficient use of energy with the current phenomenon of the limitations of its resources and the negative impact on environment is considered as one of the most burning issues of the current world [1]. Due to economic and technological advancement, most developing countries have been diverging from agriculture towards urbanization as well as industrialization for last few decades. This economic advancement is vastly dependent on the amount of energy consumed by a country. Insufficient energy supply is the main barrier to the economic growth for a developing country. Besides, the demand for industrial energy is growing by about 5\% each year [2]. Therefore, the concept of "rational use of energy" 
has been raised to reduce and optimize energy use and its limited resources, especially in industrial sectors where the rate of energy consumption is higher than any other sectors of a country [3,4].

Energy auditing is one of the most effective approaches to investigate the running energy consumption situation that leads to saving possible energy usage by means of suitable measures of an energy sector. There are several studies performed concerning energy use and energy savings considering building energy application and effects of the management structure of energy administrators on the achievement of energy efficiency $[5,6]$, impact of non-financial factors [7], flexible measures of industrial energy systems [8], primary energy use and emissions throughout the life cycle [9], energy demand in residential sectors [10,11], energy performance of specific buildings $[12,13]$ and multiple buildings or plants [14-16] and the effects of energy audit and energy policy on energy efficiency in industrial sectors [1-18]. For example, focusing on the energy consumption of an education institute in Rabigh City, Saudi Arabia, an energy audit was done by Sait [19]. The audit concluded that electrical energy consumption can be reduced by up to $35.3 \%$. A detailed energy audit on small and medium scale industries in Indonesia was performed by Priambodo and Kumar [20]. They mainly focused on energy use and the respective carbon dioxide emissions of the industries, especially in textile, fabricated metals, chemicals and food industries. The following references [3,21-24], include some related audits tackling the three factors of energy use, savings, carbon dioxide emissions and their economic and environment impacts.

It is known that a large portion of primary energy is consumed by the industrial sector in India [25]. Consequently, electrical energy demand has been increasing by about $6.13 \%$ every year during the last decade [26]. For example, in the year 2006/2007, about $44.8 \%$ of total energy was consumed by the industrial sector in India [27]. Besides, a study has been done by the International Energy Agency (IEA) which indicated that this amount of consumed energy could be more than double by 2030 [28]. Along with other industries in India, the condiment sector is one of the promising industries to meet world demand. India leads the world with regards to producing condiments. About $70 \%$ of global spice is produced by India [29]. Therefore, there are a many spice factories spread out all over the country, where the electric motor is the main appliance along with boilers, water pumps and some other appliances. The motors consume a considerable proportion of the total energy of a nation. Table 1 shows the energy consumptions by motors for a few select countries of the world [30].

Table 1. Motor energy usage around the world [30].

\begin{tabular}{cc}
\hline Country & Motor Energy Usage (\%) \\
\hline Australia & 30 \\
Brazil & 49 \\
Canada & 80 \\
China & 60 \\
EU & 65 \\
India & 70 \\
Jordan & 31 \\
Korea & 40 \\
Malaysia & 48 \\
Slovenia & 52 \\
South Africa & 60 \\
Turkey & 65 \\
UK & 50 \\
US & 75 \\
\hline
\end{tabular}

From Table 1, we can see that the motors and their related driven systems consume major portions of the energy in an industry. Therefore, it has become a necessity to consider and analyze the cost of energy and possible savings to drive the system cost-effectively. 
There are many studies done all over the world considering the energy use and energy savings in industries. For example, Christoffersen et al. [31] surveyed about 304 firms to analyze the energy management in Danish industry and proposed possible variations to improve the energy management of the concerned industries. Ozturk [32] conducted a survey on the energy consumption, energy cost and the relationship between the energy usage and textile production in the Turkish textile industry. The study focused on the effect of population growth, rapid urbanization and industrial development on energy consumption and management. Saidur et al. [33] studied the energy and emission analysis for industrial motors in Malaysia. The industrial sector consumes a massive portion of primary energy in Malaysia, where electric motors account for the largest portion of total energy used by the industrial appliances. Their study revealed that up to $3605 \mathrm{MWh}$ of electrical energy could be saved by utilizing energy-efficient motors. Bala Subramanya [34] studied brick enterprises to correlate the labor productivity, energy intensity and economic performance of small enterprises in India. Besides, having a gradual economic growth in India, energy efficiency along with energy savings has become one of the major concerns of this country. A prevalent study on energy use and savings of electric motors was done by Saidur [35]. Nadel et al. [36] performed a detailed study on energy savings, policy and related technology on electric motors. An optimization along with energy audit was done by Loganthurai et al. [37] in the granite industry. The study mainly focused on the algorithm for the optimum scheduling of various machines to reduce the demand. Besides, there are many studies to save motors' energy consumption by using variable speed drives (VSDs) and capacitor banks for power factor improvement along with regular maintenance and monitoring [33,35,36]. Besides, de Almeida et al. [38] discussed several characteristics and potentials along with the barriers and policies towards using the energy-efficient motor systems in the industrial and services sectors in the European Union. Garcia et al. [39] made a comprehensive cost-benefit analysis considering various scenarios for industrial consumers' energy-efficiency standards for electric motors in Brazilian industry. Sola and Mota [40] proposed a multi-attribute decision model for portfolio selection aiming to replace technologies in industrial motor systems that lead to surpassing various organizational barriers.

Besides electric motors, boilers consume one a major part of energy in industry. In industry, boilers are used to produce steams which consume large quantities of fossil fuels. For example, primary metals, pulp and paper, food processing, petroleum refining and chemical extraction, consume fossil fuel of about $10 \%, 81 \%, 57 \%, 23 \%$ and $42 \%$, respectively [41]. Hence, boiler energy use and savings have a huge effect on industrial application considering the economy and sustainability. To increase the boiler performance, maximizing heat transfer and minimizing heat losses is needed. To prevent heat losses in the boiler, special care should be taken regarding heat losses for hot flue gas, blow down losses and radiation losses [42]. About $10-30 \%$ of heat loss occurs during the flue-gas exhausting, which ranges between 150 and $250^{\circ} \mathrm{C}$ [43]. Therefore, there is a huge possibility to save this energy from boilers by using advance technologies that leads to minimizing losses [44,45].

Considering land-area, population and gross-domestic-product, India, Pakistan and Bangladesh are considered the largest South Asian countries. Insufficient renewable energy policies along with inadequate energy control and management strategies are impeding achieving human development and economic sustainability [46]. Salam et al. [46] focused on the energy consumption of building sectors of some South Asian countries, where they critically analyzed the main performance indicators over a period of about 50 years to intensify the existing policies, and summarized the impacts on socio-economic development of the countries. Even though they discussed several renewable energy resources to support the energy demand in building sectors, the industrial energy consumption including policies is yet to be discussed. Sharma et al. [47] investigated the practice of energy audit in India. With the help of the Energy Conservation Act 2001, the central Government and Bureau of Energy Efficiency takes required initiatives to enhance energy-productivity in 
every aspect of the economy. The study consisted of various national and international policies, standard tools and measures required for energy audit. They showed that HVAC and lighting systems might have decreased a significant amount of energy consumption for both commercial and non-commercial sectors. However, they reported that there is huge scarcity of apposite inspiration for companies to conduct energy audits as they are unaware of the advantages of it. The study mentioned that energy audits are not compulsory in India where improper economic feasibility analysis along with corresponding longer payback periods might have disinterested industries. Pandey and Prakash [48] conducted an energy audit in the pulp and paper industry in India. They estimated the electrical and thermal energy consumption of various electric pumps, boilers and lighting systems along with the reduction of $\mathrm{CO}_{2}$ emissions, and figured out the corresponding energy saving opportunities with payback periods. The study showed that almost all suggested measures (repairment or replacement) have payback periods within 12 months, where the measures (high tension capacitor bank) required to improve the power factor yielded 30-month PBP. Their work revealed that up to $5.9 \%$ energy savings is possible, where general PBP is less than 2 years in general. However, the study would be more comprehensive and would include a smart monitoring and control system to increase the energy savings and enhance the sustainability of the plant.

From the above discussion it is obvious that, there are several attempts as well as activities performed worldwide for the energy audit, while it is not a frequent activity in developing countries like India, where the industrial energy sector is a promising sector to save a significant amount of national energy. The literature survey has documented some evidence of energy audit including perspective, policies, barriers, measures and tools; the real field energy audits are very much limited in industrial sector at India. Besides, the available studies have the abridgement discussion on adequate tools, measures and energy consumption appliances. According to the above discussion and authors' best of knowledge, there are very limited studies about motors' energy use, savings and load analysis, especially in a promising industry like condiment industry in India. This study intends to explore the energy audit data to estimate motors' energy consumptions, energy savings (using VSDs) with payback period and the required power factor improvement along with boilers' performance studies and corresponding energy savings with payback period using modern technology. Finally, an advanced system has been proposed to closely monitor processing in an effort to save energy towards achieving the economic and smooth operation of the plant. This study is expected to act as a footprint for the researchers and the industrial personnel of developing countries towards achieving future economic and sustainable industrial sectors.

\section{Methodology}

The methodology comprises the detailed energy audit with targeted manufacturing factory. The process includes the description of instruments used for data collection, the approaches and mathematical equations followed to estimate energy consumption and savings and the economic analysis with payback period. These are manifested as follows:

\subsection{Targeted Manufacturing Factory}

The targeted factory of this study is a subsidiary of Plant Lipids $(P)$ Limited which is located in Kolenchery, east Cochin, India. The factory, namely, Lipids Condiment is one of the largest condiment producers in the world. It mainly produces chili powder, turmeric powder and processed pepper/powder. The average production of each product is shown in Table 2 below: 
Table 2. List of products of the plant.

\begin{tabular}{cc}
\hline Product Name(s) & Amount (ton/Month) \\
\hline Chili powder & 112 \\
Turmeric powder & 390 \\
Processed pepper & 68 \\
\hline
\end{tabular}

\subsection{A Detailed Energy Audit}

The audit team consisting of qualified and experienced electrical and mechanical engineers formally met with the appropriate plant personnel who are well versed with dayto day operation as well as physical conditions of the various machines of the plant. The team was led by an expert who is a registered energy auditor with sufficient energy audit experience, where the reliability of data collection has been ensured. The total procedures followed by the audit team during audit of the plant are listed below:

(a). At first, the members of the audit team with their target were introduced to the manager/maintenance engineer of the plant through a kick-off meeting. A review was then made by the plant manager on the manufacturing process and energy consuming machines with operation and maintenance records to give an overall idea for the audit team.

(b). After the meeting, the audit team was guided by the maintenance engineer to visit the manufacturing machines in order to observe the locations, several opportunities and the accessibility of measuring points. The representatives of respective equipment operators accompanied the audit team to describe the equipment precisely.

(c). The operating manual of the energy consuming equipment was reviewed by the audit team to obtain specifications and operating parameters.

(d). Before using the instruments, they were verified for calibration status by the facility manager and were counter checked with the online instruments installed in the facility to assure the accuracy of the data measurement.

The list of the equipment used for data collection is specified in Table 3 below:

Table 3. List of the equipment and their specifications used in the audit.

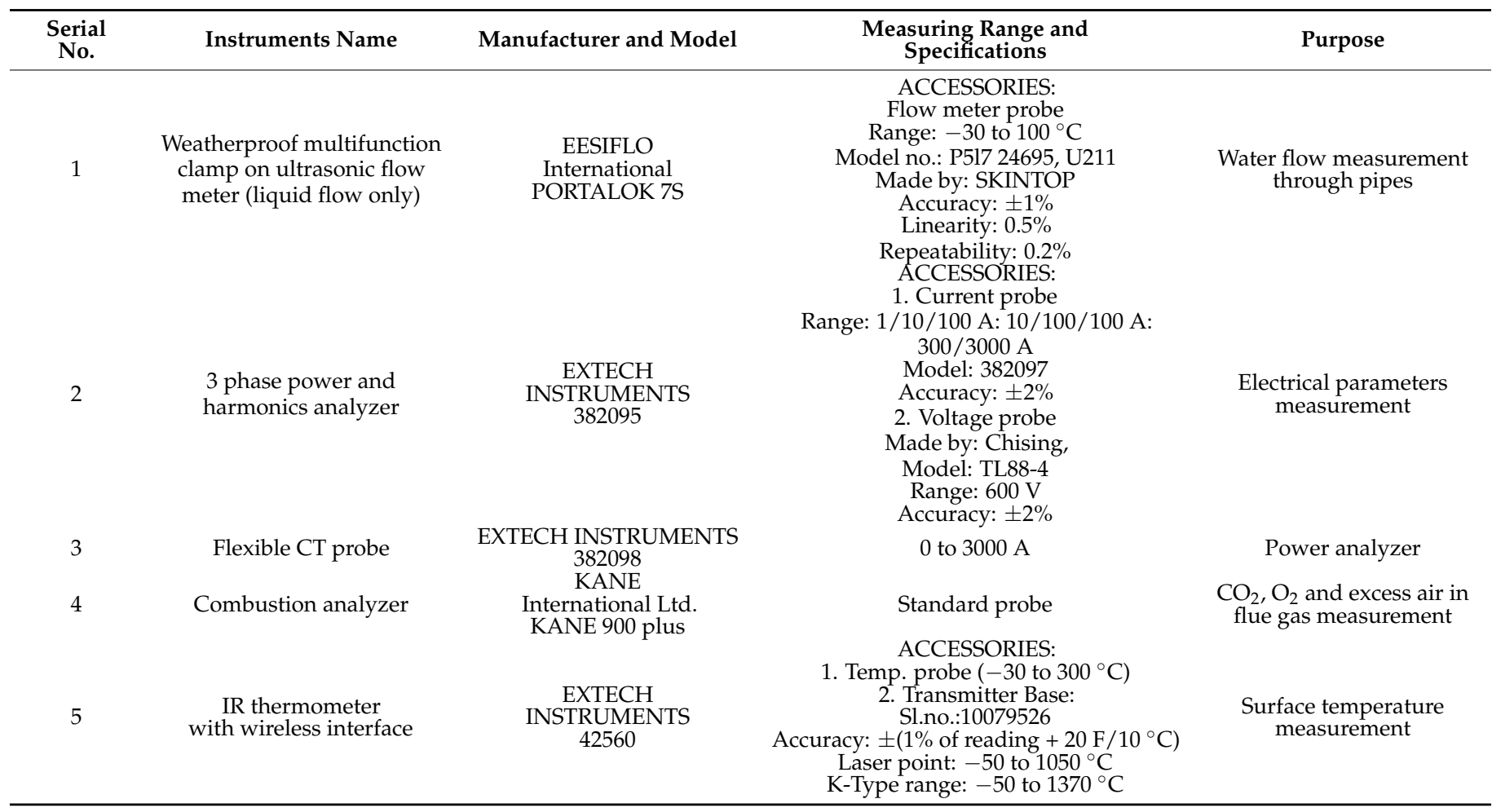




\subsection{Energy Audit Data}

The team followed a random and compatible sampling method to collect data. For getting practically acceptable results, the basic engineering skills as well as personal experience were followed to analyze the recorded data. The measured data are primary and accurate with no obscurity. Since, the data were accurate within practically acceptable error; there is no need of any statistical tool for this case.

During the audit process, the number of equipment on the production floor was counted by the audit team. The team also noted the rated powers and operating hours (per working day) of the equipment from their technical specifications. The audit team also noted the total working days per annum by consulting with the person responsible for the production process.

Power rating and total operating time of the energy consuming machineries including power factor are the most important data which were collected during the audit. Portable power meters were used to measure the actual operating data for power consumption and power factors of the machines. Furthermore, the data were analyzed to discover the energy consumption and load factors for the electric motors used in this plant. In order to save energy for motors, the VSDs were applied by taking into account the calculated load factors.

Since, the data were taken as "Business As Usual" without making any changes in the operating situation, the data collection process by means of a meter (such as power meter, electric pliers) or experimental investigation would be the best. This may help auditors to make practically implementable and economically viable recommendations to reduce energy consumption.

\section{Major Areas of Energy Consumption}

As an energy resource, biomass briquettes are used for steam production and electricity generation to run utility systems and process machineries. The annual briquette consumption is about 1080 ton. The major portion of electricity was used in chili cleaning and grinding, which was about $34 \%$ followed by air compressors, approximately $15 \%$. Among all the loads, the air compressor runs continuously for $24 \mathrm{~h}$ and consumes more electricity. The average monthly electricity consumption is $337.82 \mathrm{MWh}$ based on the financial year 2013-2014. The electricity usage is shown in Figure 1.

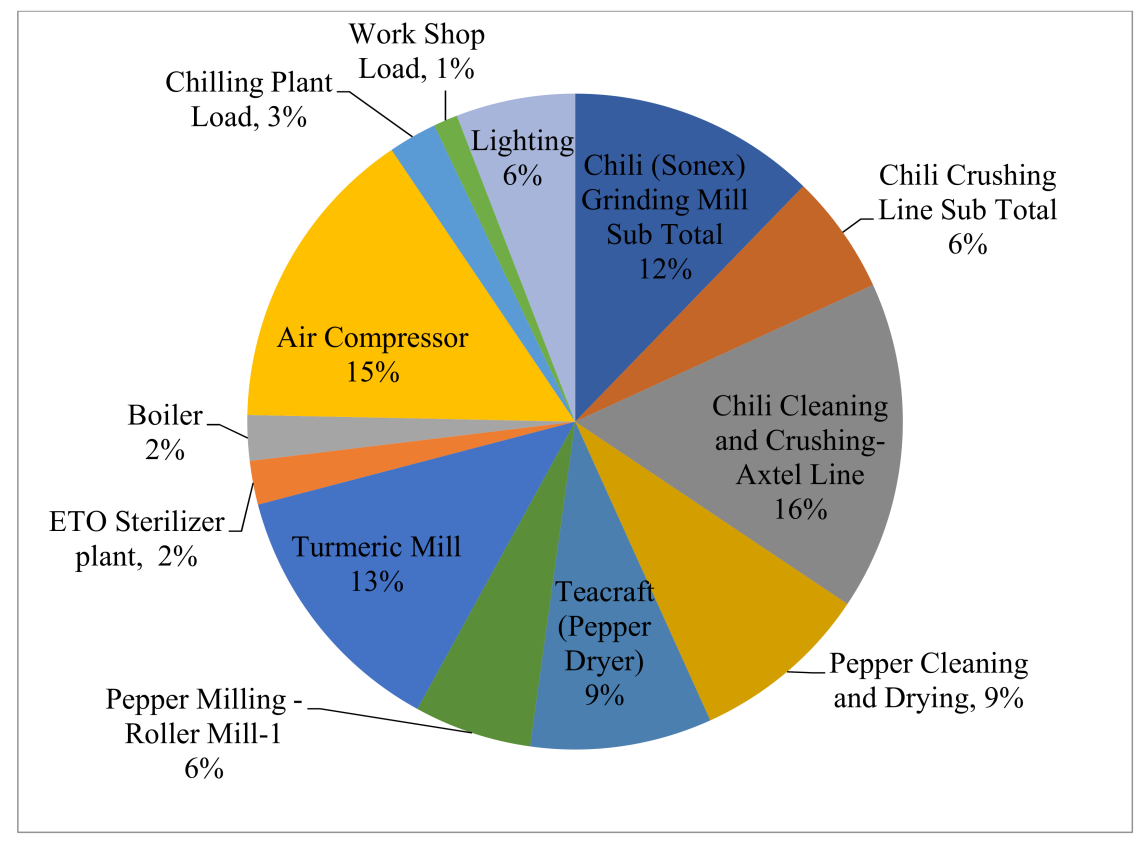

Figure 1. Electrical load sharing of the plant. 
The running electrical loads measured at each division of the plant are presented in Table 4.

Table 4. Running loads in the plant as measured during the audit.

\begin{tabular}{ccc}
\hline Sl. No & Location & $\mathbf{k W a}$ \\
& Process Machines & 23.63 \\
2 & Chili (Sonex) Grinding Mill sub total & 11.36 \\
3 & Chili Crushing Line sub total & 31.28 \\
4 & Chili Cleaning and Crushing-Axtel Line & 17.05 \\
5 & Pepper Cleaning and Drying & 17.27 \\
6 & Teacraft (pepper dryer) & 11.18 \\
7 & Pepper milling -roller mill-1 & 24.92 \\
8 & Turmeric mill & 4.15 \\
& ETO sterilizer plant & $\mathbf{1 4 0 . 8 4}$ \\
1 & Sub-Total & 4.32 \\
2 & Utility & 29.33 \\
4 & Boiler & 4.61 \\
5 & Air compressor & 2.30 \\
& Vapor Absorption Machine (VAM) & 11.32
\end{tabular}

\subsection{Mathematical Formulation}

To estimate different parameters such as load factors, energy consumption, energy saving, capacitors rating and payback periods (PBPs) some mathematical formulas are required which are presented within these subsections as follows:

\subsubsection{Load Factor}

The load factor of the motor can be calculated as [30]:

$$
L=\frac{k W_{a}}{k W_{r}}
$$

where, $k W_{a}$ and $k W_{r}$ denote actual capacity and rated capacity of an electric motor, respectively.

\subsubsection{Estimation of Energy Use}

The annual electrical energy used by the motors can be determined by the following Equation [30]:

$$
A E U=n \times P \times L \times h r
$$

where, $n, P, L$ and $h r$ represent number of motors, motor rated power $(\mathrm{kW})$, load factor (percentage of full load) (\%) and annual operating hours, respectively.

\subsubsection{Estimation of Motor Energy Saving by Using VSDs}

The annual energy savings of motors when VSDs are installed can be calculated as [30]:

$$
A E S=n \times P \times L \times h r \times S_{S R}
$$

where, $S_{S R}$ is the energy savings associated certain percentage of speed reduction (\%).

If, the standard efficient motors are replaced by high energy efficient motors, then the annual energy savings can be determined by [49]:

$$
A E S=h p \times 0.746 \times L \times h r \times\left(\frac{1}{E_{s t d}}-\frac{1}{E_{e e}}\right) \times 100
$$


where, $h, E_{s t d}$ and $E_{e e}$ denote motor rated horsepower, standard motor efficiency rating (\%) and energy efficient motor efficiency rating $(\%)$, respectively.

\subsubsection{Estimation of Boiler Energy Savings}

The heat recovered from the flue gas of the boiler can be utilized to preheat the feed water of the boiler. The heat recovery can be estimated by the following equation:

$$
Q_{f}=m_{f g} \times c_{p} \times \Delta T_{f g}
$$

where, $m_{f g}, c_{p}$ and $\Delta T_{f g}$ denote the mass flow-rate, specific heat and temperature drop of the flue gases.

The efficiency of the boiler can be calculated directly by using the equation below:

$$
\text { Boiler Efficiency }=\frac{\text { Enthalpy in Steam }}{\text { Enthalpy provided by fuel }}=\frac{Q(H-h)}{q * G C V} \times 100 \%
$$

where $Q, H, h$ and $G C V$ represent the quantity of steam generated $(\mathrm{kg} / \mathrm{h})$, enthalpy of steam $(\mathrm{Kcal} / \mathrm{kg})$, enthalpy of water $(\mathrm{kcal} / \mathrm{kg})$ and gross calorific value of the fuel, respectively. The flue gas energy analysis has been done with help of the properties of natural gas taken from the literature [36]. The costs of natural gas and oxygen trim system were considered USD 2/GJ and USD 32,000, respectively [49].

\subsubsection{Economic Analysis}

The annual bill savings (ABS) of motors associated with the above energy savings can be determined by:

$$
A B S=A E S \times C
$$

where, $C$ is the average energy cost (USD/kWh). Considering the VSDs are installed, the savings can be calculated as:

$$
A B S_{(V S D)}=A E S_{V S D} \times C
$$

\subsubsection{Payback Period}

The payback period can be determined by the following equation:

$$
P B P(\text { year })=\frac{I C_{V S D}}{A B S_{V S D}}
$$

where, IC is the incremental cost of electric motors when using VSDs has been considered as USD $80 / \mathrm{kW}$ based on industrial practice in India.

\subsubsection{Estimation of a Capacitor Rating}

It is important to determine the capacitor rating to improve the power factor. The required capacitor rating can be evaluated by the following equation:

$$
C R R=P \times\left(\tan \varphi_{1}-\tan \varphi_{2}\right)
$$

where, $P$ denotes the motor rated power $(\mathrm{kW})$. Besides, $\phi_{1}$ and $\phi_{2}$ are the existing angle and targeted angle between the real power and apparent power, respectively.

\section{Data, Result Analysis and Discussion}

The various utilities employed in the units are:

- Electricity

- Compressed air

- Specific energy consumption

- Boiler 
- Chilled water

- Motor

- Hot air system

\subsection{Electricity}

The demand for electricity of the unit is met by Kerala State Electricity Board (KSEB) grid supply and the power was drawn from 11/440 HT line with a contracted demand of $380 \mathrm{KVA}$. Considering three zones of the plant, the electrical bill analysis is shown in Table 5.

It was observed from the bill analysis (Table 5) that the average per-unit energy cost is about USD 0.091 and the average electrical power consumption per month is about 85.36 MWh. The grid power factor is maintained above 0.95 and at an average of 0.98 . The zone-wise electricity consumption is shown in Figure 2.

Peak-hour electricity consumption is about $15 \%$, which is very much on the lower side. However, the normal hour's consumption is about $51 \%$ which looks slightly on higher side. The instantly recorded power $(\mathrm{kW})$, power factor $(\mathrm{pf})$ and current $(\mathrm{A})$ are shown in Figure 3.

During the audit it was observed that one $5 \mathrm{kVAR}$ capacitor was not functioning and the automatic power factor controller was in the mode requesting it to be replaced immediately. A study on the conditions of the capacitors installed in the Automatic Power Factor Correction (APFC) panel showed that one $5 \mathrm{kVAR}$ capacitor was completely derated. There is no log sheet maintained to check the capacitor on a regular basis. Therefore, it is recommended to maintain a log sheet as shown in Table 6 to check the condition of the capacitors at regular intervals at least once a day.

Table 5. Electrical bill analysis.

\begin{tabular}{|c|c|c|c|c|c|c|c|c|}
\hline \multirow{2}{*}{ Bill Date } & \multirow{2}{*}{$\begin{array}{c}\text { Recorded } \\
\text { Demand (kVA) }\end{array}$} & \multirow{2}{*}{ Recorded Pf } & \multicolumn{3}{|c|}{ Energy Consumption (kWh) } & \multirow{2}{*}{ Total (kWh) } & \multirow{2}{*}{$\begin{array}{l}\text { Total Cost } \\
\text { (USD) }\end{array}$} & \multirow{2}{*}{ USD/kWh } \\
\hline & & & Zone 1 & Zone 2 & Zone 3 & & & \\
\hline 03-04-2014 & 264.05 & 0.98 & 49,790 & 16,030 & 31,010 & 96,830 & 7135.11 & 0.074 \\
\hline 04-03-2014 & 267.42 & 0.98 & 47,370 & 15,750 & 30,670 & 93,790 & 8470.97 & 0.090 \\
\hline 04-02-2014 & 273.22 & 0.98 & 52,335 & 17,780 & 34,875 & 104,990 & 9312.04 & 0.089 \\
\hline $07-01-2014$ & 270.41 & 0.98 & 51,565 & 17,225 & 28,865 & 97,655 & 8867.79 & 0.091 \\
\hline $05-12-2013$ & 266.53 & 0.99 & 49,805 & 15,130 & 30,010 & 94,945 & 8547.35 & 0.090 \\
\hline 05-11-2013 & 271.31 & 0.99 & 40,615 & 14,105 & 26,175 & 80,895 & 7521.63 & 0.093 \\
\hline $04-10-2013$ & 272.95 & 0.99 & 40,850 & 13,435 & 24,860 & 79,145 & 7374.44 & 0.093 \\
\hline 03-09-2013 & 267.04 & 0.99 & 44,655 & 15,810 & 29,830 & 90,295 & 8208.29 & 0.091 \\
\hline $05-08-2013$ & 261.81 & 0.99 & 38,505 & 12,355 & 25,325 & 76,185 & 7104.03 & 0.093 \\
\hline $04-07-2013$ & 260.87 & 0.99 & 34,115 & 5705 & 23,135 & 62,955 & 5906.76 & 0.094 \\
\hline $04-06-2013$ & 256.46 & 0.99 & 39,000 & 3460 & 28,630 & 71,090 & 7007.64 & 0.099 \\
\hline $04-05-2013$ & 271.95 & 0.97 & 37,470 & 13,625 & 24,430 & 75,525 & 7233.53 & 0.096 \\
\hline Average & 267.00 & 0.985 & - & - & - & - & - & 0.091 \\
\hline Total & - & - & 526,075 & 160,410 & 337,815 & $1,024,300$ & $92,689.57$ & - \\
\hline
\end{tabular}

Table 6. Proposed log sheet for capacitor checking and maintenance.

\begin{tabular}{|c|c|c|c|c|c|c|c|c|}
\hline \multirow[t]{2}{*}{ Date } & \multirow{2}{*}{ Location } & \multirow[t]{2}{*}{ Rating (kVAR) } & \multirow[t]{2}{*}{ A Rating/Ph. } & \multicolumn{3}{|c|}{$\begin{array}{c}\text { A } \\
\text { (Actual) }\end{array}$} & \multirow[t]{2}{*}{$\begin{array}{c}\% \\
\text { Derating }\end{array}$} & \multirow{2}{*}{ Remark (s) } \\
\hline & & & & $\mathbf{R}$ & $Y$ & B & & \\
\hline- & AFC Panel & 5 & 6.65 & 0 & 0 & 0 & 100 & Replace the Capacitor \\
\hline
\end{tabular}




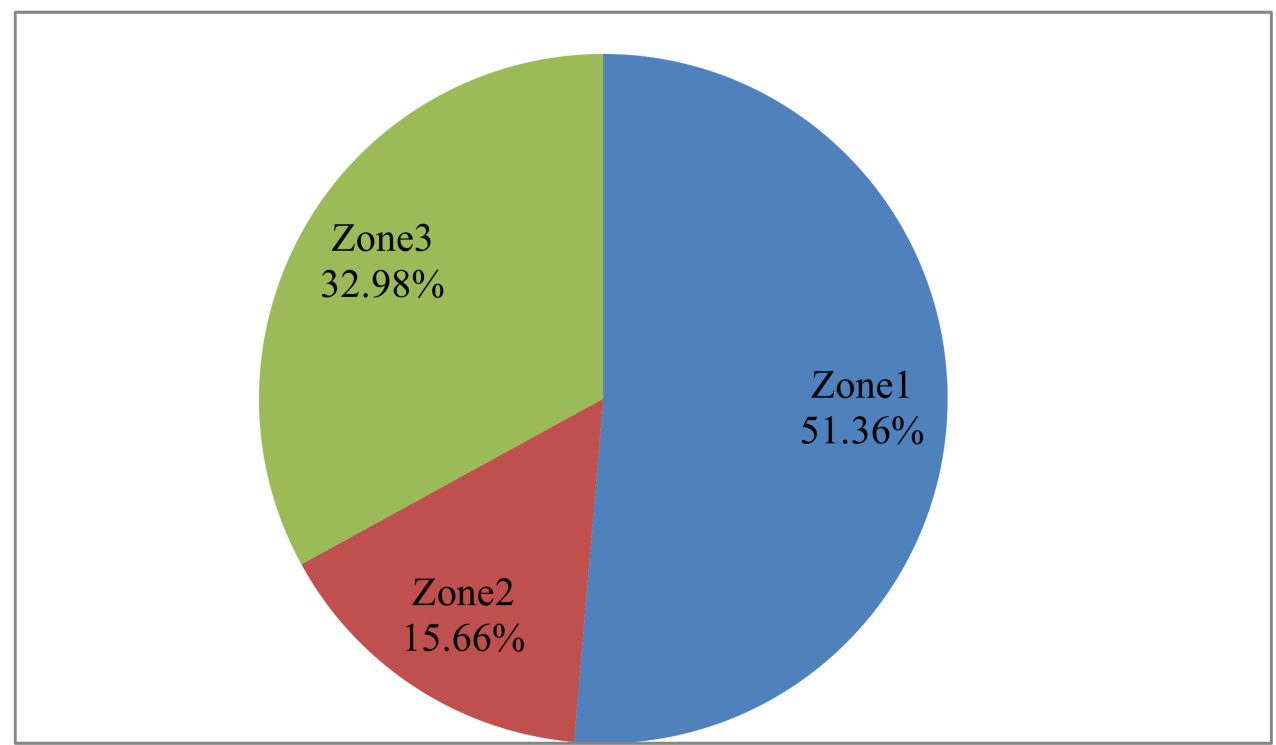

Figure 2. Electricity consumption in each zone.
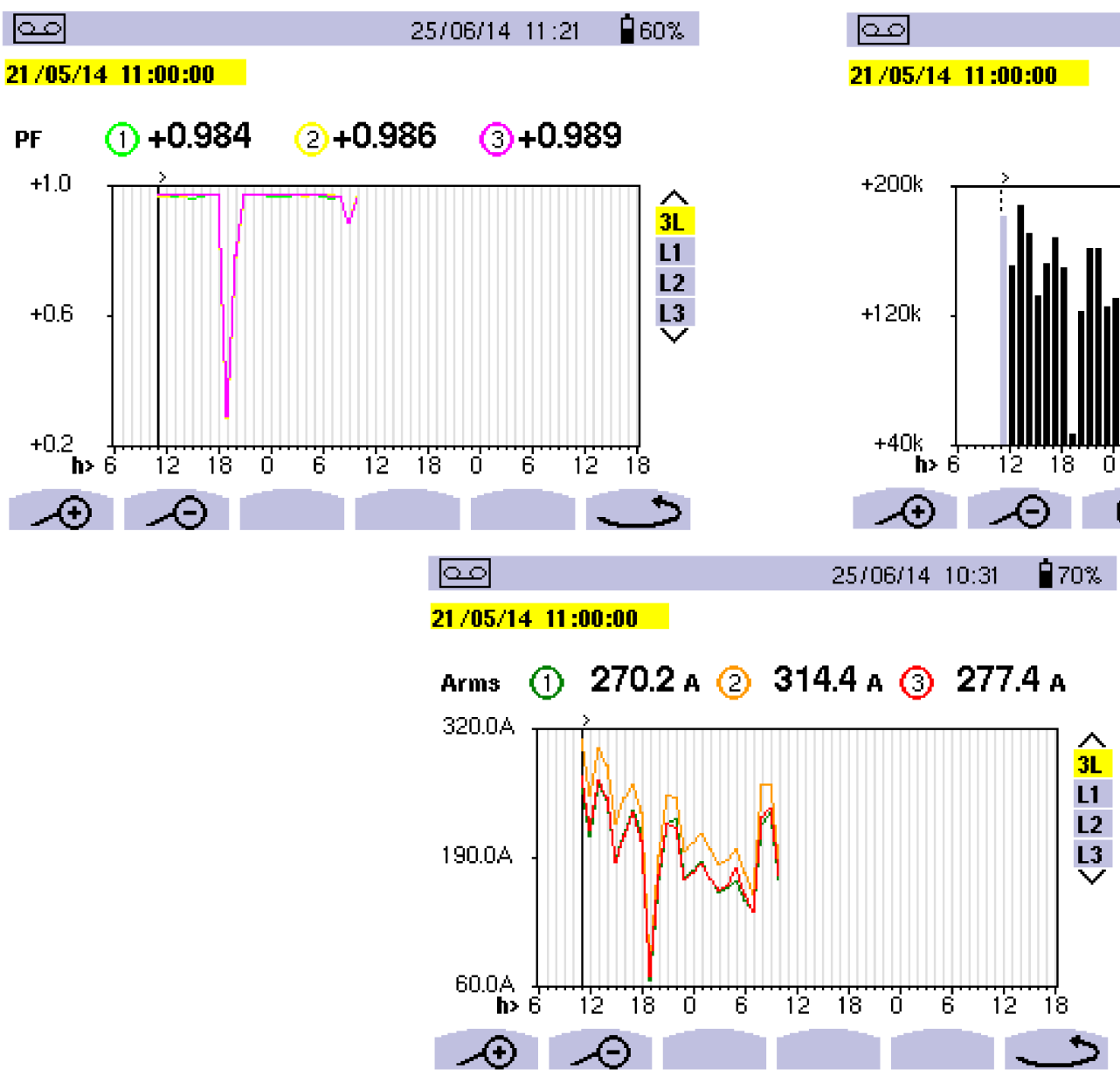

Figure 3. Recorded instant power, power factor and current.

\subsection{Compressed Air}

The unit consists of one screw type air compressor manufactured by Atlas Copco with an FAD $150 \mathrm{cfm}$ and $30 \mathrm{~kW}$ capacity. One more reciprocating compressor with a capacity of $15 \mathrm{~kW}$ with $80 \mathrm{cfm}$ free air delivery (FAD) was also available but used as a spare. Each 
compressor has separate receivers attached with a capacity of $0.5 \mathrm{~m}^{3}$. The screw compressor runs for $24 \mathrm{~h}$. and the operating pressure band is 7.9-8.9 bar. Compressed air was used in operating pneumatic valves and for cleaning purpose. Air lines are of galvanized iron (GI) pipes and run throughout the plant at an elevated location. A refrigerated air dryer was installed in each dryer.

\subsection{Specific Energy Consumption}

The specific energy consumptions estimated for the manufacture of various spice products are presented in the Table 7.

From Table 7, it is seen that the chili cleaning and crushing process has the highest energy intensity of $230 \mathrm{kWh} /$ ton followed by the turmeric mill having an energy consumption of $227.84 \mathrm{kWh} / \mathrm{ton}$.

Table 7. Specific energy consumptions.

\begin{tabular}{|c|c|c|c|c|c|c|}
\hline Plant & Power (kW) & Run (h) & $\begin{array}{c}\text { Energy } \\
\text { Consumption } \\
(\mathrm{kWh})\end{array}$ & Production (kg) & $\mathbf{k W h} / \mathbf{k g}$ & $\mathrm{kWh} /$ ton \\
\hline Sonex Grinding Mill, chili & 26.63 & 16 & 426.08 & 4375 & 0.10 & 97.39 \\
\hline $\begin{array}{l}\text { Chili Cleaning and } \\
\text { Crushing-Axtel Line }\end{array}$ & 31.28 & 16 & 500.48 & 2176 & 0.23 & 230.00 \\
\hline Teacraft- Processed Pepper & 17.27 & 24 & 414.48 & 3870 & 0.11 & 107.10 \\
\hline Pepper Milling -Roller Mill-1 & 17.18 & 16 & 274.88 & 2676 & 0.10 & 102.72 \\
\hline Turmeric Mill & 24.92 & 16 & 398.72 & 1750 & 0.23 & 227.84 \\
\hline
\end{tabular}

\subsection{Steam Generation and Boiler Performance Study}

The unit uses saturated steam at 9 bar mainly for sterilization, VAM and hot air generation for pepper drying. Steam is generated using a shell and tube industrial boiler of capacity 2 ton $/ \mathrm{h}$. There is another 1 ton/h capacity boiler installed as a stand-by. At the time of audit, a 2-ton boiler was in operation. The average fuel usage per hour was about $125 \mathrm{~kg}$. The average steam generation was $437.5 \mathrm{~kg} / \mathrm{h}$. The average calorific value of the fuel was $4200(\mathrm{G}) \mathrm{kcal} / \mathrm{kg}$. Boiler operation details are given in Table 8 .

Table 8. Boiler operation details.

\begin{tabular}{|c|c|c|}
\hline Parameter & Unit & Value \\
\hline Year of manufacture & & 1999 \\
\hline Type & & Shell and tube \\
\hline Type of fuel & & briquettes \\
\hline Evaporation capacity & $\mathrm{MT} / \mathrm{h}$ & 2 \\
\hline Steam pressure & bar & 9 \\
\hline Steam condition & - & dry \\
\hline Heat transfer area & $\mathrm{m}^{2}$ & Not available \\
\hline Feed water temperature & ${ }^{\circ} \mathrm{C}$ & 28 \\
\hline Flue gas temperature & ${ }^{\circ} \mathrm{C}$ & 260 \\
\hline Condensate return temperature & ${ }^{\circ} \mathrm{C}$ & 75 \\
\hline Is there any waste heat recovery installed & & No \\
\hline Type of draft & & Induced \\
\hline Feed water TDS & ppm & 300 \\
\hline
\end{tabular}

The boiler was operated for $24 \mathrm{~h}$ a day as well as blow down was done three times a day and the boiler is under AMC with the manufacturer. The condensate return was not used as feed water and instead it was collected in a tank and kept unutilized.

A detailed study on the 2-ton boiler was made. The observed data are presented in Table 9.

The instant performance study shows that the boiler was operated at load of less than $25 \%$. The boiler can be efficient from an economic perspective if it is operated at least at 
more than $60 \%$ of its rated capacity. The excess air is estimated at $27 \%$ based on the flue gas analysis.

Table 9. Boiler performance study.

\begin{tabular}{|c|c|c|c|}
\hline Parameter & Unit & Value & Recommended Value \\
\hline Boiler type & & $\begin{array}{l}\text { Shell and tube, } \\
\text { Two-pass }\end{array}$ & \\
\hline Made by & & Thermax & \\
\hline Rated capacity & ton $/ \mathrm{h}$ & 2 & \\
\hline Steam generation & ton $/ \mathrm{h}$ & 440 & \\
\hline Boiler loading & $\%$ & 22 & \\
\hline Steam pressure & bar & 9 & \\
\hline Steam condition & - & Dry saturated & \\
\hline Steam enthalpy & $\mathrm{Kcal} / \mathrm{kg}$ & 670 & \\
\hline Feed water temperature & ${ }^{\circ} \mathrm{C}$ & 28 & $>80$ \\
\hline Feed water enthalpy & $\mathrm{Kcal} / \mathrm{kg}$ & 28 & \\
\hline Flue gas temperature & ${ }^{\circ} \mathrm{C}$ & 260 & 180 \\
\hline Fuel type & & Briquette & \\
\hline Fuel consumption & $\mathrm{kg} / \mathrm{h}$ & 125 & \\
\hline GCV & Kcal/kg & 4200 & \\
\hline Feed water TDS & ppm & 300 & 3000 \\
\hline $\mathrm{O}_{2} \%$ in the flue gas & $\%$ & 4.5 & 8 \\
\hline Excess air & $\%$ & 27 & $<30$ \\
\hline Stoichiometric air required & $\mathrm{kg} / \mathrm{kg}$ of fuel & 11 & \\
\hline Energy recovered through air preheater & $\mathrm{kg} / \mathrm{h}$ & Nil & $\begin{array}{l}\text { Proposed to } \\
\text { install }\end{array}$ \\
\hline $\begin{array}{l}\text { Thermal efficiency based on direct } \\
\text { method }\end{array}$ & $\%$ & 56.14 & \\
\hline Condensate recovery & & Nil & \\
\hline Air preheating & & Nil & \\
\hline
\end{tabular}

\subsubsection{Condensate Recovery}

At present the plant collects the condensate from the plant and is stored in a tank and not used as boiler feed water. The heat recovery and the efficiency of the boiler were calculated using Equations (5) and (6), respectively. The measured parameters on condensate, fuel and cost saving potential are presented in Table 10.

Table 10. Energy saving opportunity in boiler through condensate recovery.

\begin{tabular}{ccc}
\hline Parameter & Unit & Value \\
\hline Condensate temperature & ${ }^{\circ} \mathrm{C}$ & 75 \\
Quantity collected & Lit/shift & 1990 \\
Heat in condensate & $\mathrm{Kcal}$ & 149,250 \\
Calorific value of fuel & $\mathrm{Kcal} / \mathrm{kg}$ & 4200 \\
Fuel equivalent (utilized) & $\mathrm{kg} / \mathrm{shift}$ & 35.53 \\
Boiler efficiency & $\%$ & 56.14 \\
Fuel equivalent input & $\mathrm{kg} / \mathrm{shift}$ & 63 \\
Operation duration/shift & $\mathrm{h}$ & 8 \\
Number of shifts in a day & - & 3 \\
Fuel saved per day & $\mathrm{kg}$ & 189 \\
Annual fuel saving for 360 days & ton & 68 \\
Cost of fuel & $\mathrm{USD} / \mathrm{ton}$ & 73.17 \\
Annual cost saving & $\mathrm{USD}$ & 4975.61 \\
Water recycled & $\mathrm{kL} / \mathrm{annum}$ & 716 \\
Cost of water & $\mathrm{USD} / \mathrm{kL}$ & 1.30 \\
Annual cost saving due to water recycling & $\mathrm{USD}$ & 931.38 \\
Total cost saving (fuel + water) & $\mathrm{USD}$ & 5907 \\
Approximate investment for installing additional collection tank, & $\mathrm{USD}$ & 5691.06 \\
pump and piping to take the condensate to feed water tank & Months & 12 \\
PBP &
\end{tabular}

By implementing these measures, the plant can reduce the boiler operational cost by approximately USD 5853.66 per annum. The water saving would be $78 \mathrm{~kL}$ and fuel saving would be 68 ton per annum. 


\subsubsection{Improving the Load on Boiler}

Steam generation in boiler at present of study was only $22 \%$ of its capacity. The plant uses a 2-ton boiler to generate steam at an average of $440 \mathrm{~kg} / \mathrm{h}$ keeping the 1-ton boiler as a stand by. The under loading of the boiler causes energy loss and it was observed that during the sudden requirement of steam, the feeding of fuel in the 1-ton boiler becomes laborious and cannot meet the requirement. Therefore, it was suggested to install a semi-automatic fuel feeding system to cope with the problem of fuel feeding (see Figure 4).
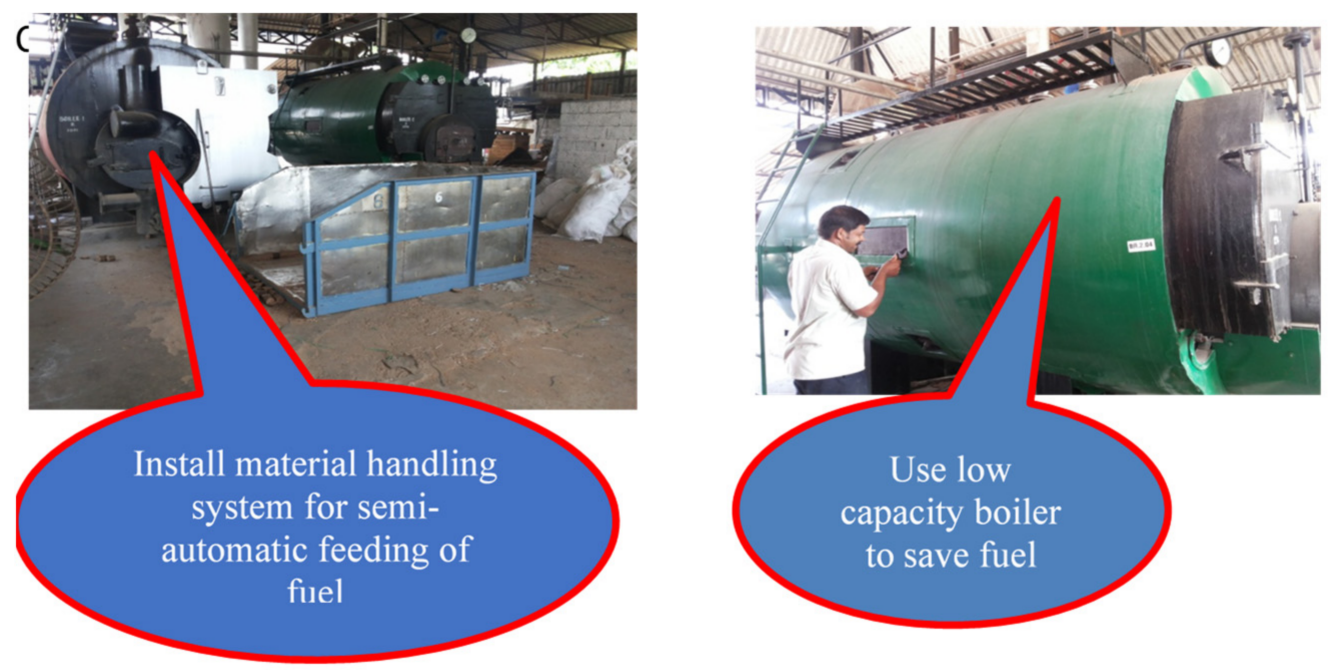

Figure 4. The current situation and suggestion for boiler performance improvement.

Optimum boiler efficiency occurs at $65-85 \%$ of full load. As the steam demand falls, so does the value of the mass flow rate of the flue gases through the tubes. This reduction in flow rate for the available heat transfer area helps to reduce the exit flue gas temperature by a small amount, reducing the sensible heat loss. However, at below $50 \%$ load, most combustion appliances need more excess air to burn the fuel completely and this would increase the sensible heat loss. Operation of a boiler at low loading should be avoided. It is practically impossible to estimate the quantum of fuel saved by increasing the boiler loading; however, there will be significant reduction in the fuel requirement by increasing the load on boiler.

By referencing the graph above (Figure 5) it is clear that boiler should not be operated at less than $25 \%$ loading and the maximum boiler efficiency occurs at a load of nearly $50 \%$. Optimum efficiency occurs where the efficiency curve meets the exit gas temperature curve. In the present case, the loading was $22 \%$ and the corresponding boiler combustion efficiency falls below $90 \%$. By improving the load to nearly $50 \%$ by using the 1 -ton boiler, the efficiency could be improved by $1 \%$. The present fuel consumption at $90 \%$ efficiency was $125 \mathrm{~kg} / \mathrm{h}$ and if the efficiency were improved by $1 \%$ the new fuel consumption would be around $123 \mathrm{~kg} / \mathrm{h}$. Thus, the annual fuel saving would be approximately 17 ton of briquettes. The corresponding cost saving would be USD 1243.90. The investment required for installing a semi-automatic fuel feeding system would be approximately USD 3252.03. The PBP for the investment would be 31 months. 


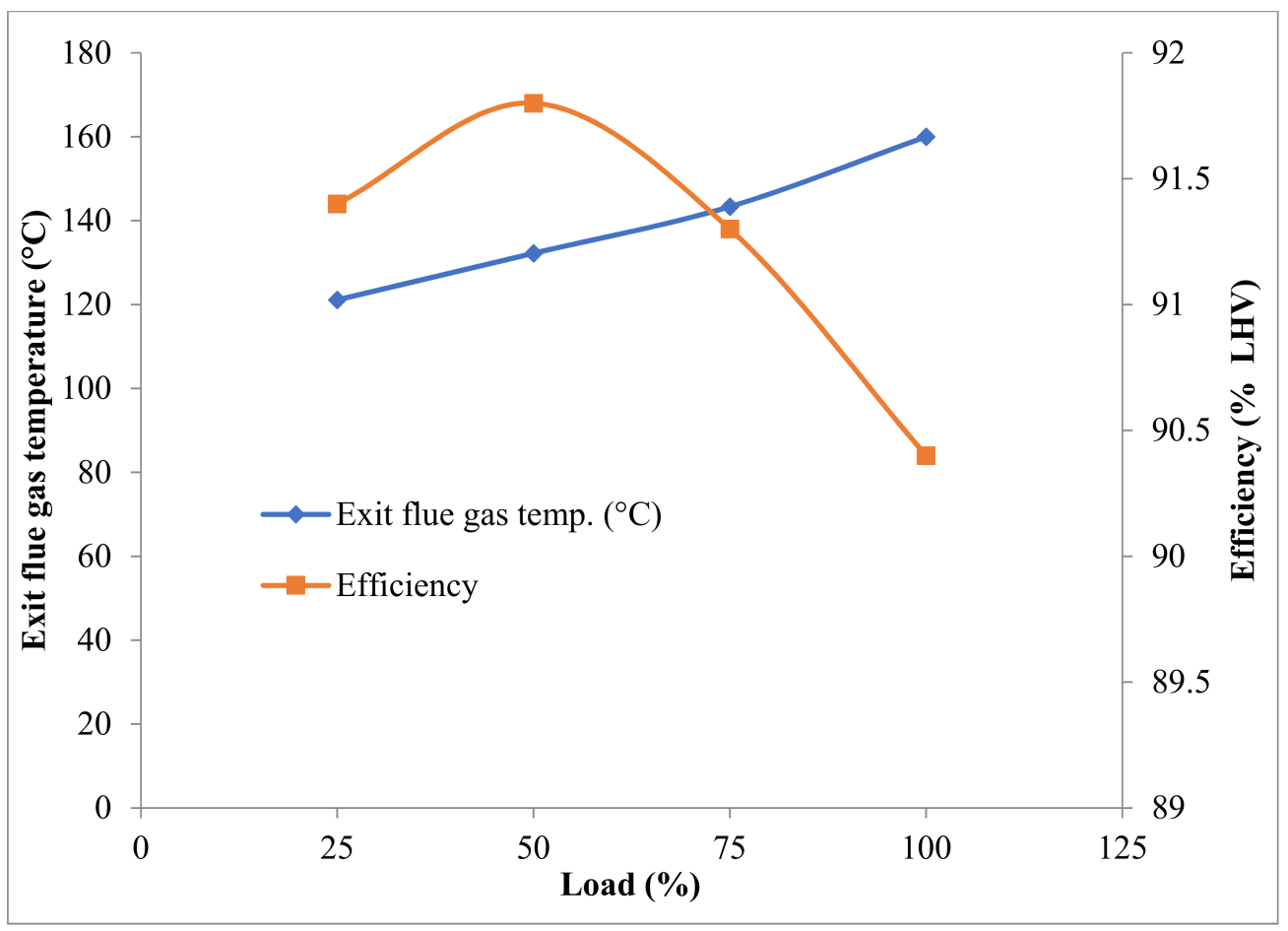

Figure 5. Performance curve of packaged boiler.

\subsection{Compressed Air System Performance}

The performance study was conducted on air compressors and the outcome of the capacity test is presented in Table 11.

Table 11. Capacity assessment test on air compressors.

\begin{tabular}{ccccccccc}
\hline Type & $\begin{array}{c}\text { Power } \\
\text { (HP) }\end{array}$ & $\begin{array}{c}\text { Rated } \\
\text { cfm }\end{array}$ & $\begin{array}{c}\text { Running } \\
\mathbf{h}\end{array}$ & $\begin{array}{c}\text { Actual } \\
\text { cfm }\end{array}$ & $\begin{array}{c}\text { Generation } \\
\text { Efficiency } \\
\mathbf{( \% )}\end{array}$ & $\begin{array}{c}\text { Operating } \\
\text { Power } \\
\text { (kW) }\end{array}$ & $\begin{array}{c}\text { Actual } \\
\text { Power } \\
\text { (kW) }\end{array}$ & $\begin{array}{c}\text { Internal } \\
\text { Leakage } \\
\text { cfm }\end{array}$ \\
\hline $\begin{array}{c}\text { Screw } \\
\text { Type }\end{array}$ & 50 & 150 & 24 & 145 & 96 & 9 & 29.33 & 10 \\
Reciprocating & 20 & 80 & Stand by & 56 & 69 & 8 & 14 & 24 \\
\hline
\end{tabular}

It was observed (see Figure 6) from the test that the screw compressor works at $96 \%$ generation efficiency and reciprocating compressor works at $69 \%$ generation efficiency However, the leakage was arrested immediately by calling the maintenance contractor as shown in the picture below.

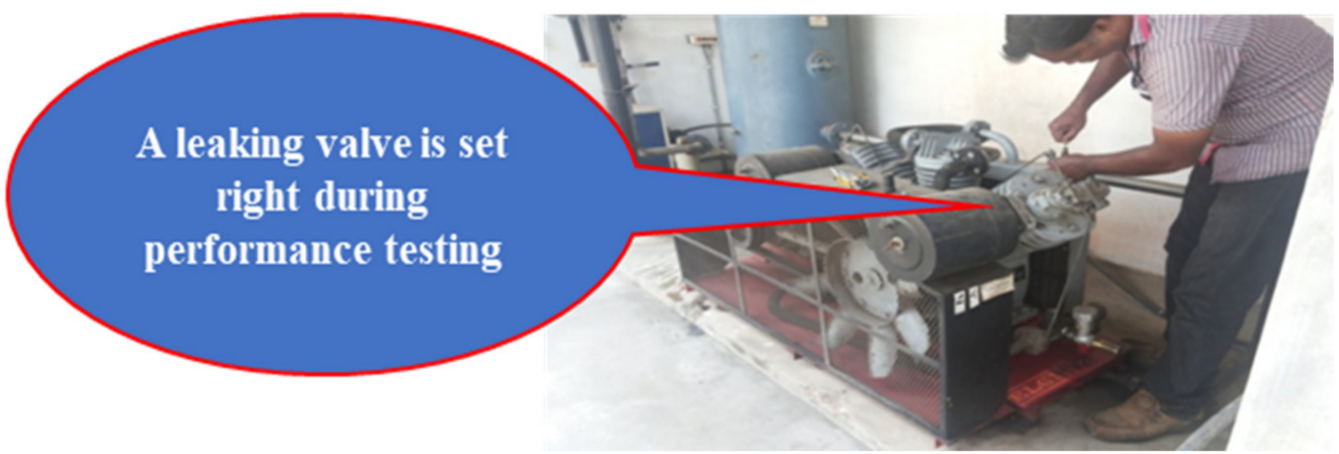

Figure 6. Leakage valve maintenance during audit.

Detailed analysis of arresting compressed air leakage is presented along with potential cost saving in Table 12. 
Table 12. Air compressor performance analysis.

\begin{tabular}{cccc}
\hline Parameter & Unit & Value & Recommended \\
\hline Type & - & Screw & \\
Make & - & Atlas Copco & \\
No. of compressor & - & Intermittent & \\
Type of loading & - & Pneumatic valve and & \\
Application & - & 8.9 & \\
Set pressure (max) & bar & 7.9 & \\
Set pressure (min) & bar & 30 & \\
Rated power & $\mathrm{kW}$ & 150 & \\
Rated FAD & $\mathrm{cfm}$ & 29.33 & @ \\
Running load & $\mathrm{kW}$ & 97.76 & generation point \\
Loading on compressor & $\%$ & 145 & \\
FAD actual & $\mathrm{cfm}$ & 0.20 & \\
Specific power consumption & $\mathrm{kW} / \mathrm{cfm}$ & 10 & \\
Leakage observed & $\mathrm{cfm}$ & 48 & \\
Energy lost per day & $\mathrm{kWh}$ & 4.34 & \\
If leakage is arrested cost & USD & 17.28 & \\
saving would be per day & MWh & 1561 & \\
Annual energy saving & USD & 813 & \\
Annual cost saving & USD & 6 & \\
Investment for leakage & Months & & \\
minimization & & & \\
Payback & &
\end{tabular}

Together with the leakage, which was observed at the generating point, there were other opportunities to reduce the energy consumption as set out below:

- Conduction of a complete leakage test in the air lines,

- Replacing the existing GI pipes with friction free aluminum pipes to reduce pressure drop,

- Grouping of cleaning points and using a separate low-capacity compressor so that air leakages can be eliminated and the use of high-pressure air can be avoided as below,

- Replacing the unused valves in receivers and other areas to avoid leakages through defective valves as shown in the Figure 7 below.

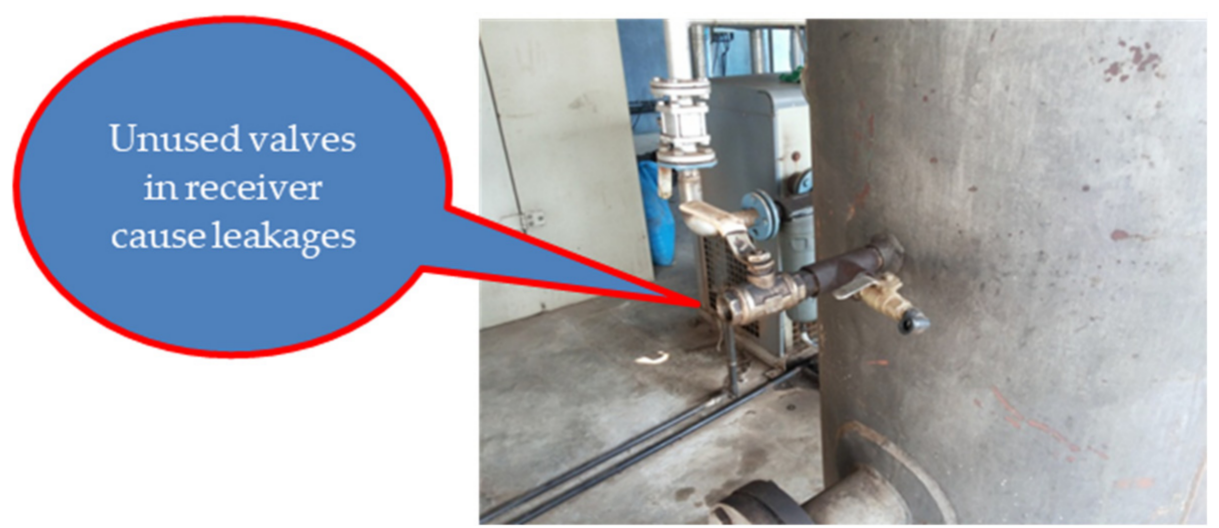

Figure 7. The unused valve which needs to be replaced to avoid leakages.

Implementing the above measures, the air compressor operating pressure band could be reduced to 6-6.5 bar. If the pressure band is reduced, the power consumption goes down to $25 \mathrm{~kW}$ and thus saving $4 \mathrm{~kW}$. Furthermore, the loading time will also get reduced. The expected saving per annum, assuming $70 \%$ loading hours per day, would be reduced to $68 \mathrm{kWh}$ per day. The annual electricity saving for 360 days would be $24,480 \mathrm{kWh}$. Therefore, the corresponding cost saving would be approximately USD 2211.38 per annum. The major investment would be replacing the compressed-air pipes. Assuming a budget provision 
of USD 4065.04 for the replacement of air pipes, the PBP for the investment would be approximately two years (23 months).

\subsection{Motor Survey}

A sample motor performance survey was conducted on various motors installed in the manufacturing machines and utility system. The measured electrical parameters for motors as well as in panels are presented in Table 13. The table contains various parameters of the electric motors such as rated power, actual power, power factor, load factor, energy use, energy saving using VSDs for three different percentages $(20 \%, 40 \%$ and $60 \%)$ of speed reduction of the motors and their corresponding annual bill savings with payback periods. Some of these parameters were directly measured and the rest were calculated by using Equations (1)-(4) and Equations (7)-(10). It may be noted that there were no VSDs installed in the plant, therefore the suggestion was made to save energy using VSDs. It is evident from the table that the payback period decreases with the increase of percentage of speed reduction using VSDs and the payback periods for most of the motors are around 1 year.

It was also observed from the survey that most of the motors have good power factors. The motor running in the hammer mill has a low power factor (pf) because of its intermittent loading on the mill. Besides, in the case of panels, the motors used in the cooling water pump, cooling tower fan, workshop panel reading, roller A, roller B, boiler total panel, water pump and DM pump have lower power factors. To improve $\mathrm{pf}$ it is suggested to add capacitors in these panels to improve pf to 0.99 , thus reducing cable losses by reducing the line current. The rating of capacitors to be added in these panels is listed in Table 14.

\subsection{Study on Pepper Dryer Hot Air System}

From the study on pepper dryer hot air system, the study observed the followings:

(i). The peppers' hot air and cold air blower system consists of one steam heater with blower for hot air generation and two cold air blowers to supply cooling air to cool the dried pepper. It was observed during the audit that:

(ii). Hot air blower and cold air blowers suction line was $80 \%$ choked.

(iii). No significant air flow was measured in these blowers.

(iv). Flow rate from dryer was measured of about $551 \mathrm{~kg} /$.

(v). Cooler surfaces were insulated.

(vi). The steam temperature was measured of about $110^{\circ} \mathrm{C}$ and the air temperature was measured of about $60^{\circ} \mathrm{C}$.

(vii). In the cold air blower suction end the filter was completely choked and there was no significant air flow observed in the blower.

(viii).The loads measured in each blower were:
Cold air blower-1
$1.71 \mathrm{~kW}$
Cold air blower-2
$2.17 \mathrm{~kW}$
Hot air blower
$2.39 \mathrm{~kW}$ 
Table 13. Load details with energy use, savings and corresponding payback periods on motors and panels.

\begin{tabular}{|c|c|c|c|c|c|c|c|c|c|c|c|c|c|c|c|}
\hline \multirow{2}{*}{ Motor's Location } & \multirow{2}{*}{ HP } & \multirow{2}{*}{$\mathrm{kWr}$} & \multirow{2}{*}{ pf } & \multirow{2}{*}{ kWa } & \multirow{2}{*}{ Load Factor, L (\%) } & \multirow{2}{*}{ AEU (MWh) } & \multicolumn{3}{|c|}{$\begin{array}{c}\text { Annual Energy Savings, } \\
\text { AES (MWh) }\end{array}$} & \multicolumn{3}{|c|}{$\begin{array}{c}\text { Annual Bill Savings, ABS } \\
\text { (USD) }\end{array}$} & \multicolumn{3}{|c|}{$\begin{array}{c}\text { Payback Period, } \\
\text { PBP (Months) }\end{array}$} \\
\hline & & & & & & & $20 \%$ & $40 \%$ & $60 \%$ & $20 \%$ & $40 \%$ & $60 \%$ & $20 \%$ & $40 \%$ & $60 \%$ \\
\hline Chili (Sonex) Grinding Mill & & & & & & & & & & & & & & & \\
\hline Pulverizer-2 & 30 & 22.38 & 0.99 & 16.60 & 74.16 & 96.94 & 19.39 & 38.78 & 58.17 & 1727.93 & 3455.86 & 5183.79 & 12 & 6 & 4 \\
\hline Conveying Blower & 15 & 11.19 & 0.98 & 6.75 & 60.30 & 39.42 & 7.88 & 15.77 & 23.65 & 702.62 & 1405.24 & 2107.87 & 15 & 7 & 5 \\
\hline Cyclon and R.A.L.V. & 7.5 & 5.60 & 0.98 & 4.62 & 82.51 & 26.98 & 5.40 & 10.79 & 16.19 & 480.91 & 961.81 & 1442.72 & 11 & 5 & 4 \\
\hline Chili Cleaning and Crushing-Axtel Line & & & & & & & & & & & & & & & \\
\hline $\begin{array}{l}\text { Conveying Blower } \\
\text { Con }\end{array}$ & 25 & 18.65 & 0.98 & 16.38 & 87.84 & 95.66 & 19.13 & 38.26 & 57.40 & 1705.03 & 3410.06 & 5115.09 & 10 & 5 & 3 \\
\hline Hammer Mill & 30 & 22.38 & 0.96 & 8.70 & 38.85 & 50.81 & 10.16 & 20.32 & 30.49 & 905.60 & 1811.20 & 2716.81 & 23 & 12 & 8 \\
\hline Blower & 5 & 3.73 & 0.98 & 3.64 & $\begin{array}{r}20.03 \\
97.68\end{array}$ & 21.26 & $\begin{array}{l}10.10 \\
4.25\end{array}$ & 8.50 & 12.76 & 378.90 & $\begin{array}{l}1011.20 \\
757.79\end{array}$ & $\begin{array}{l}2713.01 \\
1136.69\end{array}$ & 9 & 5 & 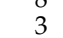 \\
\hline \multicolumn{16}{|l|}{ Pepper Cleaning and Drying } \\
\hline $\begin{array}{l}\text { Main Panel } \\
\text { Tea craft (Pepper Dryer) }\end{array}$ & 31 & 23.13 & 0.85 & 17.05 & 73.75 & 149.36 & 29.87 & 59.74 & 89.61 & 2662.16 & 5324.31 & 7986.47 & 8 & 4 & 3 \\
\hline $\begin{array}{l}\text { Dust Collector } \\
\text { D. }\end{array}$ & 7.5 & 5.60 & 0.97 & 5.25 & 93.75 & 45.99 & 9.20 & 18.40 & 27.59 & 819.73 & 1639.45 & 2459.18 & 6 & 3 & 2 \\
\hline Hot Air Blower & 7.5 & $\begin{array}{l}5.60 \\
5.60\end{array}$ & 0.97 & $\begin{array}{l}0.20 \\
2.39\end{array}$ & 42.66 & 20.94 & $\begin{array}{l}9.20 \\
4.19\end{array}$ & $\begin{array}{l}18.40 \\
8.37\end{array}$ & 12.56 & $\begin{array}{l}019.13 \\
373.17\end{array}$ & $\begin{array}{l}1639.45 \\
746.34\end{array}$ & 1119.51 & $\begin{array}{l}0 \\
14\end{array}$ & 7 & 5 \\
\hline Vacuum Sucking Motor & 7.5 & 5.60 & 0.84 & 4.75 & $\begin{array}{l}4.00 \\
84.84\end{array}$ & 41.61 & 8.32 & $\begin{array}{l}0.37 \\
16.64\end{array}$ & $\begin{array}{l}12.00 \\
24.97\end{array}$ & 741.66 & 1483.31 & 2224.97 & 7 & 3 & 2 \\
\hline Cold Air Blower -1 & 3 & 2.24 & 0.90 & 1.71 & 76.54 & 14.98 & $\begin{array}{c}0.02 \\
3\end{array}$ & 6 & 9 & 267.00 & 534.00 & 801.00 & 8 & 4 & 3 \\
\hline \multirow{2}{*}{\multicolumn{16}{|c|}{ Pepper Milling -Roller Mill-1 }} \\
\hline & & & & & & & & & & & & & & & \\
\hline Roller A & 10 & 7.46 & 0.69 & 3.41 & 45.74 & 19.91 & 3.98 & 7.97 & 11.95 & 354.95 & 709.91 & 1064.86 & 20 & 10 & 7 \\
\hline Roller B & 10 & 7.46 & 0.74 & 3.62 & 48.53 & 21.14 & 4.23 & 8.46 & 12.68 & 376.81 & 753.63 & 1130.44 & 19 & 9 & 6 \\
\hline Blower & 7.5 & 5.60 & 0.99 & 4.15 & 74.12 & 24.24 & 4.85 & 9.69 & 14.54 & 431.98 & 863.97 & 1295.95 & 12 & 6 & 4 \\
\hline \multicolumn{16}{|l|}{ Eto Sterilizer Plant } \\
\hline Water Pump & 1 & 0.746 & 0.75 & 0.64 & 85.36 & 5.61 & 1.12 & 2.24 & 3.36 & 99.93 & 199.86 & 299.79 & 7 & 3 & 2 \\
\hline \multicolumn{16}{|l|}{$\begin{array}{l}\text { Vacuum Pump } \\
\text { Boiler }\end{array}$} \\
\hline $\begin{array}{l}\text { Boiler } \\
\text { Water pump }\end{array}$ & 5 & 3.73 & 0.51 & 1.94 & 52.03 & 16.99 & 3.40 & 6.80 & 10.20 & 302.91 & 605.82 & 908.73 & 12 & 6 & 4 \\
\hline D M pump motor & 1 & 0.746 & 0.72 & 0.43 & 58.23 & 3.77 & 0.75 & 1.51 & 2.26 & 67.14 & 134.28 & 201.42 & 10 & 5 & 3 \\
\hline Atlas Copco Compressor & 40 & 30 & 0.91 & 29.33 & 97.76 & 256.93 & 51.39 & 102.77 & 154.16 & 4579.53 & 9159.07 & $13,738.6$ & 6 & 3 & 2 \\
\hline $\begin{array}{l}\text { LG Screw Compressor } \\
\text { Chilling Plant }\end{array}$ & 20 & 14.92 & 0.90 & 9.28 & 62.20 & 81.29 & 16.26 & 32.52 & 48.78 & 1448.96 & 2897.93 & $\begin{array}{l}13,700.0 \\
4346.89\end{array}$ & 10 & 5 & 3 \\
\hline Cooling water pump & 5 & 3.73 & 0.65 & 2.27 & 60.74 & 19.89 & 3.98 & 7.95 & 11.93 & 354.43 & 708.87 & 1063.30 & 10 & 5 & 3 \\
\hline Cooling tower fan & 5 & 3.73 & 0.51 & 2.34 & 62.83 & 20.50 & 4.10 & 8.20 & 12.30 & 365.36 & 730.73 & 1096.09 & 10 & 5 & 3 \\
\hline
\end{tabular}


Table 14. Recommended rating of capacitors to improve pf in panels.

\begin{tabular}{rcccccc}
\hline $\begin{array}{r}\text { S1. } \\
\text { No }\end{array}$ & Location & Load (kW) & $\begin{array}{c}\text { Pf } \\
(\mathbf{O l d})\end{array}$ & $\begin{array}{c}\text { Pf } \\
\mathbf{( N e w )}\end{array}$ & $\begin{array}{c}\text { Capacitor } \\
\text { Power Rating, } \\
\text { CPR (kVAr) }\end{array}$ & $\begin{array}{c}\text { Suggested Rating } \\
\text { (kVAr) }\end{array}$ \\
\hline 1 & Cooling water pump & 2.27 & 0.65 & 0.99 & 2.33 & 3 \\
2 & Cooling tower fan & 2.34 & 0.51 & 0.99 & 3.61 & 4 \\
3 & Workshop panel reading & 2.3 & 0.53 & 0.99 & 3.35 & 4 \\
4 & Roller A & 3.41 & 0.69 & 0.99 & 3.09 & 3 \\
5 & Roller B & 3.62 & 0.74 & 0.99 & 2.77 & 3 \\
6 & Boiler total panel & 1.94 & 0.59 & 0.99 & 2.38 & 3 \\
7 & Water pump & 1.94 & 0.51 & 0.99 & 0.35 & 1 \\
8 & D M pump motor & 0.43 & 0.72 & 0.99 & & 3 \\
\hline
\end{tabular}

It was recommended to implement the following to improve the dryer performance and reduce the power consumption:

$>$ Regular cleaning of steam heater coil and improve air flow.

$>$ Removing the insulation from cooler surfaces.

$>$ Isolating the dryer area from cooler area by providing partition strips.

$>$ One cooler having the suction near steam trap fan can be removed.

$>$ Cleaning the suction filter of the second cooler fan and improve air flow. This flow can be split and connected to the cooler.

$>$ The steam heater was placed at the suction end of the hot air blower. It was recommended to place the steam heater on the delivery side of the steam heater.

$>$ The higher velocity of air at delivery end of the blower will enhance the heat transfer rate and improve efficiency of heat utilization.

$>$ At present, the blower handles hot air thus reducing flow rate due to hot gas. If the blower handles cold air, the specific energy consumption will decrease, and flow rate will increase (see Figure 8).

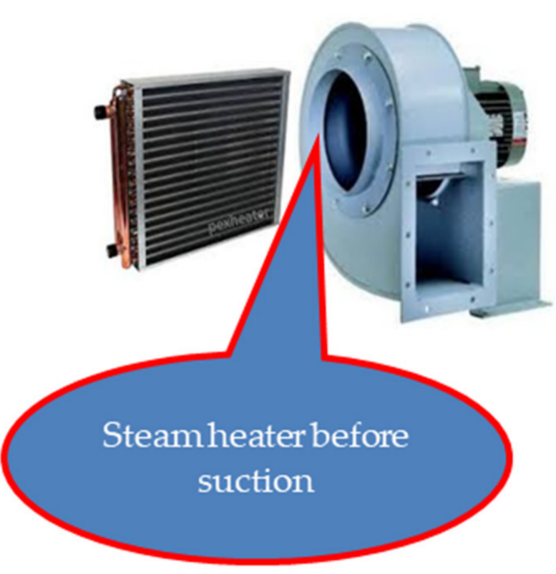

EXISTING

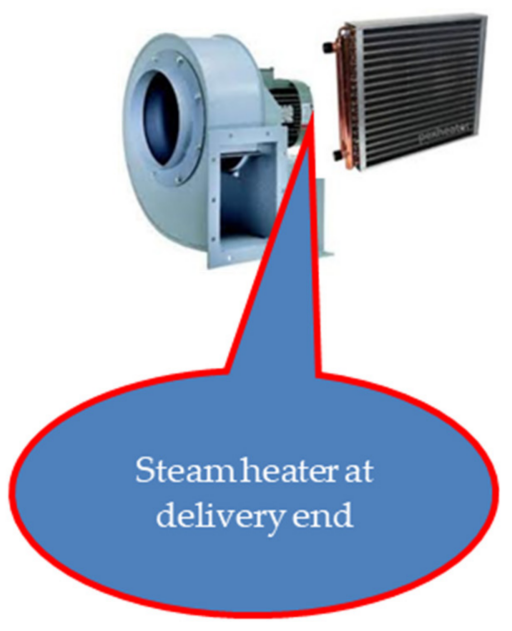

PROPOSED

Figure 8. The current and proposed position of heat exchanger to increase the performance.

By rectifying the steam heat exchanger arrangement, the hot air temperature could be increased to $90{ }^{\circ} \mathrm{C}$. There is a possibility to increase the drying speed and thus increase the production to $1000 \mathrm{~kg} / \mathrm{h}$ from the dryer for the same energy consumption. With these measures implemented, one cold air blower would be sufficient to supply cold air and the other blower could be removed as shown in the Figure 9 below. 


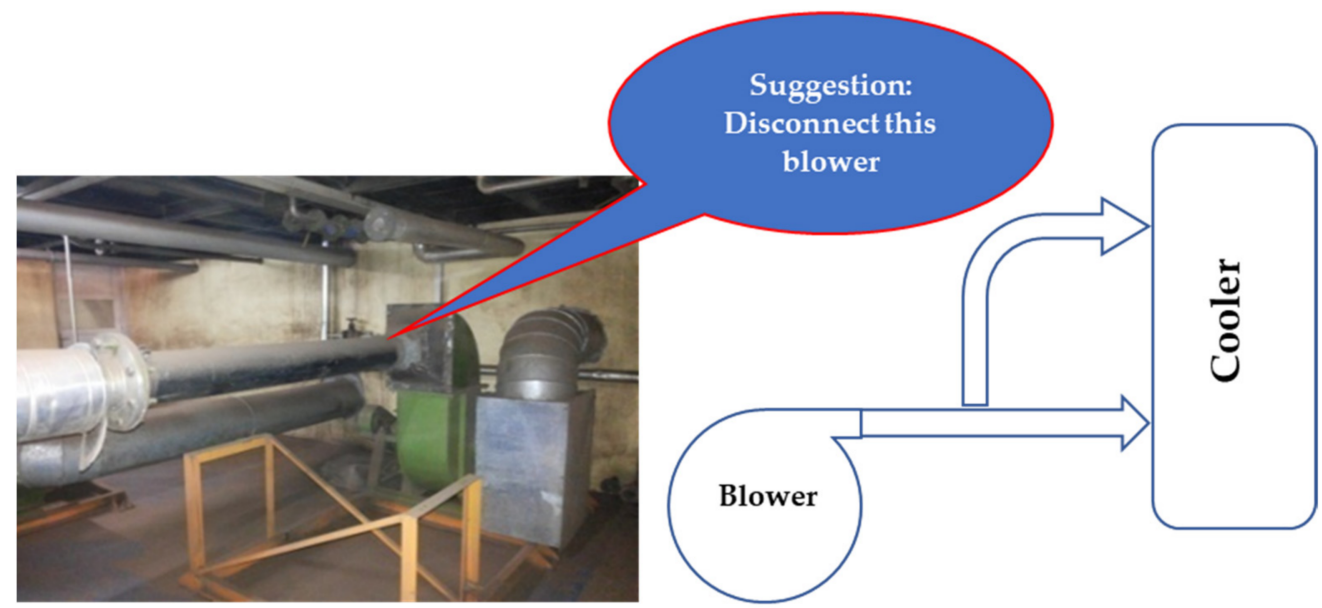

Existing connection

Suggested connection

Figure 9. The suggestion to remove one blower for energy saving.

By removing one blower, the expected power reduction is $1.71 \mathrm{~kW}$ and the annual reduction in electricity consumption would be $14.77 \mathrm{MWh}$. The corresponding cost saving would be USD 1333.33. Investment for the proposed measure is very nominal and PBP will be immediate.

\subsection{Cooling Tower Fan}

An FRP cooling tower was installed in the plant to cool the condenser water coming from VAM. The fan is driven by a $5 \mathrm{HP}$ motor and the power drawn was measured of about $2.73 \mathrm{~kW}$. The fan maintains a single speed and runs $24 \mathrm{~h}$ a day. It was recommended to switch off the fan based on cooling water outlet temperature particularly during winter and rainy seasons. By installing a commercially available cooling tower fan energy saver, fan operation could be optimized and an energy saving of $10 \%$ per annum is possible. Thus, the fan energy consumption could be reduced by $2358 \mathrm{kWh}$ per annum. The corresponding cost saving would be USD 211.38. The cost of the energy saver is approximately USD 122 and PBP for the investment is about 7 months.

\subsection{Improving Monitoring and Control of Energy Consumption}

Close monitoring and controlling of energy consumption help to benchmark and fix target energy consumption in various production activities as well as in utility systems. This leads to a conservative estimation of 3-5\% energy saving per annum. To do that, the plant can install sub-meters with GPRS modem for remote measuring and monitoring of electricity consumption in the following panels:

- Main panel

- Turmeric plant

- Chili plant

- Pepper plant

- VAM

- Air compressors

The schematic diagram of the smart metering system is shown in the Figure 10 below:

The various electrical parameters from the above meters will be collected remotely to a central PC. The data will be analyzed by the new energy analysis software tool named "SMART JOULES" to provide an insight into the electrical energy consumption pattern. The tool has various features as follows:

- Hourly energy consumption in a graphical form with values.

- Profile/trend chart for pf and KVA.

- A comparative chart on hourly/monthly/yearly energy consumption along with cost. 
- Prediction feature to estimate future demand.

- Mail alerts in case of nearing target values of energy consumption.

- Feature to enter production/fuel consumption/water consumption data manually.

- Generate report on specific energy/fuel/water consumption and energy saving potential in case of low power factor.

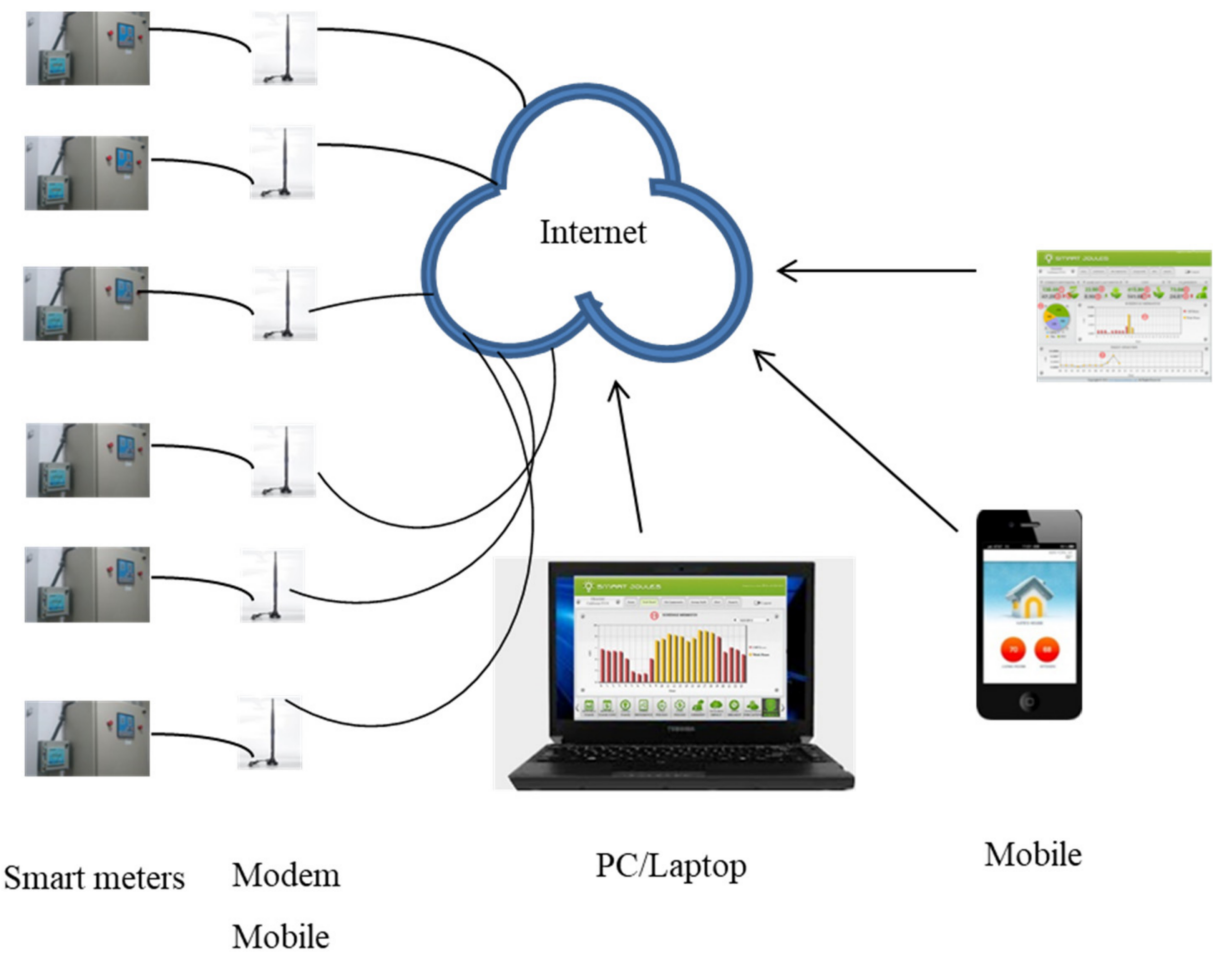

Figure 10. The proposed digital monitoring system using Smart Joules software.

The Smart Joules software can be integrated into the production monitoring software already installed in the plant.

The energy saving estimation using “The Smart Joules" software is presented in Table 15.

Table 15. Energy saving estimation by installing "Smart Joules".

\begin{tabular}{ccc}
\hline Parameters & Unit & Value \\
\hline Present annual energy consumption & $\mathrm{kWh}$ & $1,024,300$ \\
Cost of energy & USD & 0.091 \\
Estimated energy saving & $\%$ & 3 \\
Estimated annual energy saving in absolute value & $\mathrm{kWh}$ & 30,729 \\
Annual cost saving & USD & 2764.23 \\
Investment for "Smart Joules" for connecting 30 energy meters & USD & 4471.55 \\
and one software license & months & 19 \\
Payback period &
\end{tabular}

Smart energy meters with GPRS modem can be installed quickly and connected to the PC through the Internet. It avoids cabling and works maintenance-free forever.

\subsection{Energy Conservation Options and Recommendations}

The various energy conservation opportunities are listed with recommendations in Table 16. 
Table 16. List of energy saving options with recommendations.

\begin{tabular}{|c|c|c|c|c|c|c|}
\hline Area & Recommendations & $\begin{array}{l}\text { Estimated Energy } \\
\text { Saving (MWh/y) }\end{array}$ & $\begin{array}{l}\text { Estimated Fuel } \\
\text { Saving (Ton/y) }\end{array}$ & $\begin{array}{l}\text { Estimated Cost } \\
\text { Saving (USD) }\end{array}$ & $\begin{array}{l}\text { Estimated } \\
\text { Investment } \\
\text { (USD) }\end{array}$ & $\begin{array}{l}\text { Payback } \\
\text { (Month) }\end{array}$ \\
\hline \multirow{2}{*}{ 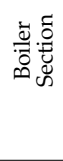 } & Condensate Recovery & - & 78 & 5902.44 & 5691.06 & 12 \\
\hline & $\begin{array}{l}\text { Installing fuel feeding system to improve the loading } \\
\text { and efficiency of boiler }\end{array}$ & - & 17 & 1243.90 & 3252.03 & 31 \\
\hline \multirow{2}{*}{ 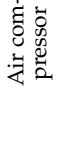 } & $\begin{array}{l}\text { Arresting air leakage within compressor and receiver } \\
\text { system }\end{array}$ & 17.28 & - & 1560.98 & 813.01 & 6 \\
\hline & $\begin{array}{l}\text { Revamping pipelines, grouping cleaning points and } \\
\text { reduce pressure bad }\end{array}$ & 24.48 & - & 2211.38 & 4065.04 & 24 \\
\hline 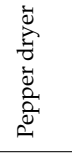 & $\begin{array}{l}\text { Improve maintenance of suction side of cold air } \\
\text { blowers and install steam heater at delivery section. } \\
\text { Remove one cold air blower }\end{array}$ & 14.77 & - & 1333.33 & Nominal & Immediate \\
\hline 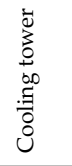 & Installing cooling tower fan energy saver & 2.35 & - & 211.38 & 121.95 & 7 \\
\hline 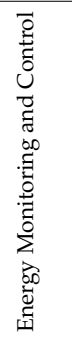 & Installing smart metering system & 30.73 & - & 2764.23 & 4471.55 & 19 \\
\hline & Total & 89.61 & 95 & $15,227.64$ & $18,414.63$ & 15 \\
\hline
\end{tabular}

\section{Conclusions}

Using the energy audit acquires prominent value in the field of industry as it gives us a clear idea about recent energy consumption along with possible energy savings. The present study represents a detailed energy audit in a condiment plant in India. The audit consists of the energy use and possible energy savings of various electric motors along with two boilers installed in the plant. The major findings of this study are summarized below:

(a) The process of chili cleaning and grinding causes the highest energy consumption (about $34 \%$ of total energy) and highest energy intensity $(230 \mathrm{kWh} / \mathrm{ton})$ followed by air compressors, approximately $15 \%$, and the turmeric mill, about $227.84 \mathrm{kWh} /$ ton, respectively.

(b) The average electrical power consumption per month is about $85.36 \mathrm{MWh}$, where the grid power factor is maintained above 0.95 and at an average of 0.98 .

(c) The nonfunctioning capacitor ( $5 \mathrm{kVAR}$ ) would be replaced by APFC panel to improve the power factor of the system.

(d) Energy savings from electric motors can be obtained by using VSDs to ensure maximum energy savings of about 827.10 MWh per annum with PBP below 1 year (in most cases) if the speed of the motors is reduced by about $60 \%$.

(e) The measures considered for condensate recovery of the boilers leads to a reduction of the boiler operational cost by approximately USD 5853.66 per annum, where the water and fuel saving would be $78 \mathrm{kLand} 68$ ton per annum, respectively.

(f) The enhancement of boilers loading (from $22 \%$ to $50 \%$ ) enables an annual fuel saving of approximately 17 ton of briquettes, where the PBP of the measures taken is found to be about 31 months.

(g) In the case of the panel, the motors used in the cooling water pump, cooling tower fan, workshop panel reading, roller A, roller B, boiler total panel, water pump and D $\mathrm{M}$ pump have lower power factors (between 0.51 and 0.74 ) which causes huge energy 
losses. Therefore, capacitors of required ratings are suggested for all these motors to enhance the power factor by up to 0.99 .

(h) An air-preheater has been suggested to be installed at the output of the boiler to extract the heat from exhausting flue gas which is vastly suitable to preheat the input steam. This measure enables about 68 tons of fuel savings per annum with a PBP of 1 year.

(i) A digital system using "The Smart Joules" software has been proposed to be installed in the plant which will monitor the whole energy system of the plant. This managed to save about $3-5 \%$ of total energy per annum with the PBP about one and half years.

Therefore, it can utterly be concluded that there are several areas including related tools and measures occupied in the industries, where prospective measures along with the upgradation as well as inclusion of new technologies offers enormous potentiality to minimize energy consumption by dispelling energy loss that leads towards economic and sustainable energy consumption by industrial sectors. Therefore, this study will help researchers and industrial personnel of developing countries towards achieving economic and sustainable industrial sector status in the future.

Author Contributions: K.R.U.: methodology, formal analysis, and writing-original draft preparation; M.T.: practical data collection, report writing and reviewing-real field data collection, reviewing and drafting; R.S.: supervision, conceptualization, and writing-review and editing; K.A.R.: formal analysis, visualization, and writing - review and editing; M.R.K.: data curation, visualization, and writing - review and editing. All authors have read and agreed to the published version of the manuscript.

Funding: This research received no external funding.

Institutional Review Board Statement: Not applicable.

Informed Consent Statement: Not applicable.

Data Availability Statement: The data may be available on request to the authors.

Acknowledgments: The authors are cordially thankful to the authority and respective people of the Plant Lipid (P) Limited, Kolenchery, Cochin, India to give the opportunity for energy audit as well as the cordial co-operation during the audit period.

Conflicts of Interest: The authors declare no conflict of interest.

\begin{tabular}{|c|c|}
\hline Abbre & ations \\
\hline The fol & wing abbreviations are used in this $n$ \\
\hline ABS & Annual Bill Savings \\
\hline AES & Annual Energy Savings \\
\hline AEU & Annual Electrical Energy \\
\hline APFC & Automatic Power Factor Correction \\
\hline CRR & Capacitor Rating Required \\
\hline FAD & Free Air Delivery \\
\hline IEA & International Energy Agency \\
\hline $\mathrm{L}$ & Load Factor \\
\hline PBP & Payback Period \\
\hline PF & Power Factor \\
\hline$Q_{f}$ & Heat Recovery \\
\hline VAM & Vapor Absorption Machine \\
\hline VSD & Variable speed drive \\
\hline
\end{tabular}

\section{References}

1. Johansson, I.; Mardan, N.; Cornelis, E.; Kimura, O.; Thollander, P. Designing Policies and Programmes for Improved Energy Efficiency in Industrial SMEs. Energies 2019, 12, 1338. [CrossRef]

2. Mongia, P.; Schumacher, K.; Sathaye, J. Policy reforms and productivity growth in India's energy intensive industries. Energy Policy 2001, 29, 715-724. [CrossRef] 
3. Akash, B.A.; Mohsen, M.S. Current situation of energy consumption in the Jordanian industry. Energy Convers. Manag. 2003, 44, 1501-1510. [CrossRef]

4. Yau, H.Y.; $\mathrm{Ng}$, W.K. A comparison study on energy savings and fungus growth control using heat re-covery devices in a modern tropical operating theatre. Energy Convers. Manag. 2011, 52, 1850-1860. [CrossRef]

5. Pritoni, M.; Paine, D.; Fierro, G.; Mosiman, C.; Poplawski, M.; Saha, A.; Bender, J.; Granderson, J. Metadata Schemas and Ontologies for Building Energy Applications: A Critical Review and Use Case Analysis. Energies 2021, 14, 2024. [CrossRef]

6. Liao, F.-F.; Chen, W.-H. Will the Management Structure of Energy Administrators Affect the Achievement of the Electrical Efficiency Mandatory Target for Taiwan Factories? Energies 2021, 14, 2021. [CrossRef]

7. Milojević, M.; Urbański, M.; Terzić, I.; Prasolov, V. Impact of Non-Financial Factors on the Effectiveness of Audits in Energy Companies. Energies 2020, 13, 6212. [CrossRef]

8. Tristán, A.; Heuberger, F.; Sauer, A. A Methodology to Systematically Identify and Characterize Ener-gy Flexibility Measures in Industrial Systems. Energies 2020, 13, 5887. [CrossRef]

9. Luna-Tintos, J.F.; Cobreros, C.; López-Escamilla, Á.; Herrera-Limones, R.; Torres-García, M. Methodology to Evaluate the Embodied Primary Energy and $\mathrm{CO}_{2}$ Production at Each Stage of the Life Cycle of Prefabricated Structural Systems: The Case of the Solar Decathlon Competition. Energies 2020, 13, 4311. [CrossRef]

10. Oh, S.; Kim, C.; Heo, J.; Do, S.L.; Kim, K.H. Heating Performance Analysis for Short-Term Energy Monitoring and Prediction Using Multi-Family Residential Energy Consumption Data. Energies 2020, 13, 3189. [CrossRef]

11. Dall'O, G.; Sarto, L.; Panza, A. Infrared Screening of Residential Buildings for Energy Audit Purposes: Results of a Field Test. Energies 2013, 6, 3859-3878. [CrossRef]

12. Salvadori, G.; Fantozzi, F.; Rocca, M.; Leccese, F. The Energy Audit Activity Focused on the Lighting Systems in Historical Buildings. Energies 2016, 9, 998. [CrossRef]

13. Rospi, G.; Cardinale, N.; Negro, E. Energy Performance and Economic Feasibility Study of Historical Building in the City of Matera, Southern Italy. Energies 2017, 10, 2009. [CrossRef]

14. Chan, M.H.E.; Chu, K.-K.; Chow, H.-F.; Tsang, C.-W.; Ho, C.K.D.; Ho, S.-K. Improving the Energy Efficiency of Petrochemical Plant Operations: A Measurement and Verification Case Study Using a Balanced Wave Optimizer. Energies 2019, 12, 4136. [CrossRef]

15. Hwang, K.D.; Cho, J.; Moon, J. Feasibility Study on Energy Audit and Data Driven Analysis Proce-dure for Building Energy Efficiency: Bench-Marking in Korean Hospital Buildings. Energies 2019, 12, 3006. [CrossRef]

16. González, G.A.; García-Sanz-Calcedo, J.; Salgado, D.R. Evaluation of Energy Con-sumption in German Hospitals: Benchmarking in the Public Sector. Energies 2018, 11, 2279. [CrossRef]

17. Franzitta, V.; Longo, S.; Sollazzo, G.; Cellura, M.; Celauro, C. Primary Data Collection and Environmental/Energy Audit of Hot Mix Asphalt Production. Energies 2020, 13, 2045. [CrossRef]

18. Locmelis, K.; Blumberga, D.; Blumberga, A.; Kubule, A. Benchmarking of Industrial Energy Efficiency. Outcomes of an Energy Audit Policy Program. Energies 2020, 13, 2210. [CrossRef]

19. Sait, H.H. Auditing and analysis of energy consumption of an educational building in hot and humid area. Energy Convers. Manag. 2013, 66, 143-152. [CrossRef]

20. Priambodo, A.; Kumar, S. Energy use and carbon dioxide emission of Indonesian small and medium scale industries. Energy Convers. Manag. 2001, 42, 1335-1348. [CrossRef]

21. Ilic, D.D.; Trygg, L. Economic and environmental benefits of converting industrial processes to district heating. Energy Convers. Manag. 2014, 87, 305-317. [CrossRef]

22. Engin, T.; Ari, V. Energy auditing and recovery for dry type cement rotary kiln systems-A case study. Energy Convers. Manag. 2005, 46, 551-562. [CrossRef]

23. Hepbasli, A.; Ozalp, N. Development of energy efficiency and management implementation in the Turkish industrial sector. Energy Convers. Manag. 2003, 44, 231-249. [CrossRef]

24. Ozkan, B.; Akcaoz, H.; Karadeniz, F. Energy requirement and economic analysis of citrus production in Turkey. Energy Convers. Manag. 2004, 45, 1821-1830. [CrossRef]

25. Bellarmine, T.G.; Arokiaswamy, N.S.S. Energy management techniques to meet power shortage problems in India. Energy Convers. Manag. 1996, 37, 319-328. [CrossRef]

26. Mathur, J.; Bansal, N.K.; Wagner, H.-J. Investigation of greenhouse gas reduction potential and change in technological selection in Indian power sector. Energy Policy 2003, 31, 1235-1244. [CrossRef]

27. Dutta, M.; Mukherjee, S. An outlook into energy consumption in large scale industries in India: The cases of steel, aluminium and cement. Energy Policy 2010, 38, 7286-7298. [CrossRef]

28. Gielen, D.; Taylor, P. Indicators for industrial energy efficiency in India. Energy 2009, 34, 962-969. [CrossRef]

29. Spice. 2014. Available online: http:/ / en.wikipedia.org/wiki/Spice (accessed on 26 June 2014).

30. Thirugnanasambandam, M.; Hasanuzzaman, M.; Saidur, R.; Ali, M.B.; Rajakarunakaran, S.; Devaraj, D.; Rahim, N.A. Analysis of electrical motors load factors and energy savings in an Indian cement industry. Energy 2011, 36, 4307-4314. [CrossRef]

31. Christoffersen, B.L.; Larsen, A.; Togeby, M. Empirical analysis of energy management in Danish industry. J. Clean. Prod. 2006, 14, 516-526. [CrossRef]

32. Öztürk, H.K. Energy usage and cost in textile industry: A case study for Turkey. Energy 2005, 30, 2424-2446. [CrossRef] 
33. Saidur, R.; Rahim, N.A.; Ping, H.; Jahirul, M.; Mekhilef, S.; Masjuki, H. Energy and emission analysis for industrial motors in Malaysia. Energy Policy 2009, 37, 3650-3658. [CrossRef]

34. Bala Subrahmanya, M. Labour productivity, energy intensity and economic performance in small enterpris-es: A study of brick enterprises cluster in India. Energy Convers. Manag. 2006, 47, 763-777. [CrossRef]

35. Saidur, R. A review on electrical motors energy use and energy savings. Renew. Sustain. Energy Rev. 2010, 14, 877-898. [CrossRef]

36. Nadel, S. Energy-Efficient Motor Systems: A Handbook on Technology, Programs, and Policy Opportunities; Amer Council for an Energy: Washington, DC, USA, 2000.

37. Loganthurai, P.; Rajasekaran, V.; Gnanambal, K. Optimization of operating schedule of machines in granite industry using evolutionary algorithms. Energy Convers. Manag. 2014, 86, 809-817. [CrossRef]

38. De Almeida, A.T.; Fonseca, P.; Bertoldi, P. Energy-efficient motor systems in the industrial and in the services sectors in the European Union: Characterisation, potentials, barriers and policies. Energy 2003, 28, 673-690. [CrossRef]

39. Garcia, A.G.P.; Szklo, A.S.; Schaeffer, R.; McNeil, M.A. Energy-efficiency standards for electric motors in Brazilian industry. Energy Policy 2007, 35, 3424-3439. [CrossRef]

40. Sola, H.A.V.; Mota, C.M.d.M. A multi-attribute decision model for portfolio selection aiming to replace technologies in industrial motor systems. Energy Convers. Manag. 2012, 57, 97-106. [CrossRef]

41. Einstein, D.; Worrell, E.; Khrushch, M. Steam Systems in Industry: Energy Use and Energy Efficiency Improvement Potentials; Lawrence Berkeley National Laboratory: Berkeley, CA, USA, 2001.

42. ERC, I. How to Save Energy and Money in Boilers and Furnace Systems; Energy Research Centre (ERC), University of Cape Town: Cape Town, South Africa, 2004.

43. Jayamaha, L. Energy-Efficient Building Systems: Green Strategies for Operation and Maintenance; McGraw Hill Professional: New York, NY, USA, 2006.

44. Yeh, S.; Rubin, E.S. A centurial history of technological change and learning curves for pulverized coalfired utility boilers. Energy 2007, 32, 1996-2005. [CrossRef]

45. Saidur, R.; Ahamed, J.; Masjuki, H. Energy, exergy and economic analysis of industrial boilers. Energy Policy 2010, 38, $2188-2197$. [CrossRef]

46. Salam, R.A.; Amber, K.P.; Ratyal, N.I.; Alam, M.; Akram, N.; Gómez Muñoz, C.Q.; García Márquez, F.P. An Overview on Energy and Development of Energy Integration in Major South Asian Coun-tries: The Building Sector. Energies 2020, 13, 5776. [CrossRef]

47. Sharma, P.; Mahajan, R.; Sharma, Y. Investigation of the Energy Audit Practice in India. Int. J. Res. Anal. Rev. $2018,5,767-772$.

48. Pandey, A.K.; Prakash, R. Energy Conservation Opportunities in Pulp \& Paper Industry. Open J. Energy Effic. 2018, 07, 89-99. [CrossRef]

49. Carpenter, K.; Kissock, K.; D'Antonio, M. Common excess air trends in industrial boilers with single-point positioning control and strategies to optimize efficiency. In ACEEE Summer Study on Energy Efficiency in Industry; American Council for an Energy-Efficient Economy: Washington, DC, USA, 2007. 